ASARC Working Paper 2012/03

Revised on 12 April, 2012

\title{
Have Natural Disasters Become Deadlier?
}

\author{
Raghav Gaiha ${ }^{1}$, Kenneth Hill ${ }^{2}$ and Ganesh Thapa ${ }^{3}$
}

\author{
To be given at the NBER conference on \\ Catastrophic Risks and Insurance, \\ Cambridge, MA, 11-12 ${ }^{\text {th }}$ May 2012.
}

Contact address:

Raghav Gaiha, Faculty of Management Studies,

University of Delhi, Delhi -110007, India.

Email: gaiha@mit.edu. Tel: 9111-26108293.

1. ASARC, Arndt-Corden Department of Economics, Australian National University

2. Harvard Centre for Population and Development Studies

3. International Fund for Agricultural Development 


\begin{abstract}
The present study seeks to build on earlier work by identifying the factors associated with the frequency of natural disasters and the resulting mortality. Drawing together the main findings, some observations are made from a policy perspective to focus on key elements of a disaster reduction strategy.

Countries that were prone to natural disasters in the previous decade (1970-79) continued to be so in the next two decades. Geophysical factors (e.g. whether landlocked, distance to coast) had an important role in explaining inter-country variation in the occurrence of natural disasters. However, income did not have any effect.

Deaths varied with the number of disasters; they also varied with (lagged) deaths in the previous decade, pointing to (presumably) persistent government failures in preventing deaths where the deaths were high; poor countries suffered more deaths, controlling for these and other effects; larger countries suffered more deaths.
\end{abstract}

The pay-off from learning from past experience is high, as reflected in the elasticity of deaths to disasters. Even moderate learning can save a large number of deaths (e.g. through early warning systems, better coordination between governments and communities likely to be affected). Growth acceleration would also help avert deaths through more resources for disaster prevention and mitigation capabilities. A combination of the two-learning from past experience and more resources for disaster prevention and mitigation-would of course result in a massive reduction in deaths from disasters.

Attention is drawn to segmented and shallow disaster insurance markets; the Samaritan's dilemma in providing emergency assistance to poor countries that neglect investment in protective measures; need for mainstreaming of disaster prevention and mitigation among multilateral development agencies and governments, as also growth acceleration ; why short-term relief must be combined with rebuilding of livelihoods and reconstruction, and the potential for public-private partnerships; and, above all, the need for building ownership of local communities and preservation of social networks.

A challenge for development assistance is to combine growth acceleration with speedy relief and durable reduction in vulnerability to natural disasters.

Key words: disasters, deaths, vulnerability, insurance, reconstruction.

JEL codes: Q54, Q57, I 12 


\title{
Have Natural Disasters Become Deadlier? ${ }^{1}$
}

\author{
Introduction
}

A consensus is beginning to emerge that local institutions, governments and development agencies have to pay greater attention to building resilience against natural disasters. This culminated in the World Conference on Disaster Reduction (WCDR) in Kobe in January, 2005. Some recent analyses (e.g. World Bank, 2006, 2010, Birkmann, 2006, Kahn, 2005, Gaiha and Thapa, 2006, The Economist, 2012) point to greater vulnerability to such disasters, reflected in a marked increase in the frequency of their occurrence, and in their costliness in recent years.

The present study seeks to build on earlier work by identifying the factors associated with their frequency and the resulting mortality. Drawing together the main findings, some observations will be made from a policy perspective to focus on key elements of a disaster and mortality reduction strategy.

Natural disasters affect household welfare in three distinct ways: loss of physical integrity, assets and income. Injuries, fatalities and health epidemics compromise the quality of life. ${ }^{2}$ Loss of assets is equally common. Houses, for example, are highly vulnerable to the damaging impact of earthquakes, high winds, volcanic eruptions, landslides and floods. Loss of income from flooded arable land, damaged food crops and reduced agricultural production may be temporary or of a long-term nature.

Few would question the rising cost of natural disasters-especially in developing countries. The Indian Ocean tsunami in December 2004 killed over 250,000 people, followed by the earthquake centred on Kashmir that killed tens of thousands and left over 3 million homeless. ${ }^{3}$ Meanwhile, poor harvests and pests threaten famine in the Sahel and Southern

\footnotetext{
${ }^{1}$ Raghav Gaiha would like to acknowledge the financial support from IFAD and excellent research facilities provided by Harvard's Centre for Population and Development Studies and Department of Global Health and Population. Discussions with and /or comments by Vinod Thomas, T. Elhaut, David Bloom, Anil Deolalikar, Katsushi Imai, Sonia Bhalotra, Dan Bromley, R. Jha, M. Walton, Shantanu Mathur, Vani S. Kulkarni, Varsha S. Kulkarni, Nidhi Kaicker , S. Vaid and Alankrita Pandey were valuable in carrying out the present analysis. A special word of praise for David Hargitt and Regina Below, who promptly responded to our requests for updates of EM-DAT and our queries. The computations were carried out with admirable efficiency by Raj Bhatia. The present version benefited greatly from the comments made at a seminar at the Centre for Population and Development Studies at Harvard. Any deficiencies that remain are, however, the authors' responsibility.

${ }^{2}$ Renaud (2006) throws light on the persistent dangers and health risks of the 2004 tsunami in Sri Lanka, through deterioration of water quality. Communities, for example, reported "salinity, nauseating odours and coloured water...more than a year after the event” (p.121).

${ }^{3}$ According to a report in The New York Times, of the 30, 000 people killed by the 2004 tsunami in Sri Lanka, at least 10,000 were children. On the same proportion, as many as 50,000 children died in South Asia on 26 December, 2004 (Rohde, 3 April, 2005).
} 
Africa. The overall picture of disaster impacts is one of large-scale human suffering, loss of lives and a precipitous rise in financial costs. The global costs of natural disasters have risen 15-fold since the 1950s, and more sharply in recent years. ${ }^{4}$

Another way of looking at damages is that they dilute hard-won development gains. In Mozambique, for example, the floods of 2000 damaged or destroyed about 500 primary schools and 7 secondary schools. The Kashmir earthquake of 2005 also was massive in its impact, as the damages totaled \$5billion-roughly equivalent to the total ODA for the preceding three years (World Bank, 2006). What adds to the longer-term impact is the effect on investment-especially in agriculture-through a dampening of 'the animal spirits'.

In an imaginary world of full and complete markets, poor households could protect themselves by insuring themselves against asset and income losses and by borrowing. In the real world, however, natural shocks decapitalise and impoverish them. A recent investigation of the impact of 1998 Hurricane Mitch in Honduras, and of a drought in Ethiopia (19982000) illustrates partial recovery of the poor in terms of asset and income smoothing (Carter et al. 2007).

While we are wary of making generalizations, often women bear the brunt of such disasters. ${ }^{6}$ Only one woman for every three men survived the December 2004 tsunami in a district in Aceh (Indonesia). In two other districts, women accounted for 77 and 80 per cent of deaths (Oxfam, 2005). Women's deaths outnumbered men's also in the 1991 Bangladesh cyclone and the 1993 Maharashtra (India) earthquakes (World Bank, 2006).

As a broad classification, two types of hazards are distinguished: hydro-meteorological (e.g. floods, droughts, storms) and geophysical (e.g. earthquakes, volcanic eruptions and related

\footnotetext{
${ }^{4}$ (a) Disaster costs in material losses rose from \$38 billion (at 1998 values) in 1950-59 to \$652 billion in 199099 (World Bank, 2006). More recent evidence points to falling death rates but sharply rising economic losses in recent years. “....multi-billion dollar natural disasters are becoming common. Five of the ten costliest, in money rather than lives, were in the past four years ......Munich Re, a reinsurer, reckons their economic costs were \$378 billion last year, breaking the previous record of \$262 billion in 2005 (in constant 2011 dollars)" ("Counting the Cost of Calamities”, The Economist, January $14^{\text {th }}$, 2012).(b) Hallegate and Przyluski (2010) point out the difficulties in defining, measuring and predicting the total cost of disasters. The emphasis is on indirect (output) losses as a major component of the total loss of welfare. But there are insufficient data and inadequate methodologies. Specific network-shaped economic sectors (e.g electric system, water distribution, transportation) are especially important but other sectors also involve networks through supply chains. So failure in one system may rupture production in another (fewer supply chains in one may enhance vulnerability of another).

${ }^{5}$ For details, see Gaiha and Thapa (2006). There is, however, some macro-economic evidence favouring speedy recovery (Andersen, 2005).

${ }^{6}$ Wisener (2006) rejects the widely used taxonomy of the vulnerable (comprising women, children and elderly people), as it produces far too many 'false positives'. An important point to bear in mind, however, is that age and sex patterns of deaths resulting from rapid onset extreme events (e.g. earthquakes, floods) may differ from others (e.g. droughts, famines). Dyson's (1991) analysis of deaths in the Bengal famine of 1943 and Bangladesh famine of 1974-75, for example, shows that the mortality of males was higher than that of females. Differences between male-female mortality rates were large in the prime adult age groups. The reasons included differences in migration propensities, higher levels of women's body fat, and, more importantly, lower levels of pregnancy and lactation among women arising from anticipatory fertility decline.
} 
tsunamis), as their impacts differ. ${ }^{7}$ This is in part due to differences in their frequencies of occurrence and predictability. These differences are discussed in Annex 2.

\section{Issues}

The present study is motivated by a broader concern for human well-being in which resilience against natural disasters is a key element. A specific concern is that often natural disasters are far deadlier in low income countries. For example, between 1980-2002, India experienced 14 major earthquakes that killed 32117 people while the United States experienced 18 major earthquakes that killed barely 143 people (Kahn, 2005). Our study is designed to throw light on the underlying geographic, institutional and development variables. Specifically, the following issues are addressed:

- Have natural disasters become more frequent?

- Does their occurrence vary across different regions?

- Have the death tolls of these disasters increased in more recent years?

- Do death tolls vary across different regions?

- How important is the role of geophysical and climate related factors in the causation of different types of natural disasters?

- Do relatively affluent countries suffer fewer deaths?

- Do institutions matter? Specifically, whether there are fewer deaths in a democracy?

- Does ethnic/linguistic/religious fragmentation make it harder to avert deaths?

- Does higher frequency of disasters in a previous period induce better disaster preparedness?

- Is the pay-off to disaster prevention high? Specifically, whether learning from past experience helps save lives? Also, is the pay-off from a combination of learning and accelerated growth in the poorest countries substantially greater?

Some of these issues are addressed in Kahn (2005). The specifications and sample used, however, differ, as also the findings. Briefly, countries which did not report natural disasters for three years in a row or with a large number of zeros in the disaster death counts were excluded. Also, some of the specifications used are contentious. ${ }^{8}$

\footnotetext{
${ }^{7}$ For definitions of natural hazards, see Table A.1.1 in Annex 1.

${ }^{8}$ When the number of disasters in a country is known, it is intriguing why a probit is used that allows for a dichotomous classification of whether a country experienced a natural disaster or not. More seriously, while occurrence of natural disasters is endogenous, in mortality equations number of natural shocks/ disasters is treated as exogenously determined. So changes in some of the important results (e.g. role of higher incomes, institutions and geography) and the conclusions linked to them cannot be ruled out.
} 


\section{Data}

These issues are addressed with the help of a data base compiled from EM-DAT, WDI, FAOSTAT, and from the website of the Kennedy School at Harvard. ${ }^{9}$ The main component is EM-DAT which covers all countries over the entire $20^{\text {th }}$ century. Along with a description of the types of disasters, their dates and locations, the numbers killed, injured, made homeless and otherwise affected are reported. An event qualifies for inclusion in EM-DAT if it is associated with (i) 10 or more people reported killed; or (ii) 100 or more people affected, injured or homeless; or (iii) a declaration of a state of emergency and/or an appeal for international assistance made. ${ }^{10}$

As the EM-DAT quality has improved in the 1970s and to focus better on changes in recent years, the present analysis uses the data for the period 1980-2004, with different sub-periods for specific exercises.

A recent review draws attention to the following problems/gaps in the EM-DAT: ${ }^{11}$

- Data coverage is incomplete for several categories. The numerical data categories (e.g. numbers killed, total affected) are unsatisfactorily represented before 1970, with many recorded events having no entries for numbers killed or total affected. Even after this year, data are patchy for some countries and event types.

- According to a report by Working Group 3 of the Inter-Agency Task Force of the International Strategy for Disaster Reduction (ISDR), a comparison between EM-DAT and the DesInventar disaster database (http://www.desinventar.org) for Chile, Jamaica, Panama and Colombia shows that differences in numbers of people "affected" are substantial. Differences in numbers "killed" are, however, much smaller and "generally of the same order of magnitude" (Brooks and Adger, 2005, cited on p.15). Larger discrepancies in the numbers affected are due to underreporting in DesInventar, suggesting that EM-DAT are more reliable. In any case, a general consensus is that mortality data are more robust across different data sets. ${ }^{12}$

- The economic losses consist of direct and indirect components (Andersen, 2005). The direct losses refer to the physical destruction of assets, comprising private dwellings, small business properties, industrial facilities, and government assets including infrastructure (e.g. roads, bridges, ports, telecommunications) and public facilities (e.g. hospitals, schools). The indirect losses, on the other hand, refer to disruption of economic activities, and loss of employment and livelihoods. In addition, business pessimism could dampen investment and consequently growth. So the relationship between destruction of

\footnotetext{
${ }^{9}$ Other specialized sources include Alesina et al. (2003). They have constructed by far the most comprehensive indicators of ethnic, linguistic and religious fractionalization. Another important source on geographical and political regime characteristics is Gallup et al. (1999).

10 As argued later, while hazards may be natural (e.g. tsunamis, cyclones, earthquakes), disasters are often man made. Death tolls in a famine or an earthquake vary with the speed of relief provided by governments, communities and donors.

${ }^{11}$ For details, see Brooks and Adger (2005).

${ }^{12}$ For further validation, see Annex 3.
} 
capital and loss of income may vary a great deal. ${ }^{13}$ Although there has been a sharp rise in economic losses-especially in recent years- the available estimates are incomplete and unreliable. These are compiled from a variety of sources including insurance companies, multilateral institutions and the news media. It is thus plausible that insured losses are better covered and, consequently, there is significantly lower coverage of losses in developing countries (Andersen, 2005). Accordingly, the economic losses are not analysed.

An issue of considerable importance is whether natural disasters in rich countries are distinguishable from those in less affluent countries. A recent World Bank study (2006) points out that there is no private insurance against natural hazard risk in most developing countries. Specifically, while about half of the costs of natural disasters are covered by insurance in the United States, less than 2 per cent of them are covered in the developing world. Besides, the costs of hedging against natural hazard risks in developing countries often exceed the cost of simply paying for the damages when they occur. Finally, both awareness of and preparedness for such risks are much greater in rich countries. We have accordingly restricted our analysis to the sample of countries other than the rich (including OECD and non-OECD groups).

\section{Frequency and Deadliness of Natural Disasters}

Let us first consider the frequency distributions of natural disasters and their deadliness. ${ }^{14}$ These are given in Table 1. Note that the averages are not meant to illustrate trends.

- In the aggregate sample, floods were the most frequent disaster, accounting for well over one-third of the total disasters during 1985-94. The next most frequent were windstorms that accounted for over a quarter of the disasters.

- With the exception of insect infestations, all natural disasters became more frequent in the next period (i.e. 1995-2004). While the share of floods rose, that of windstorms declined. Numbers of droughts and famines rose while that of insect infestations declined. While the share of droughts also rose, those of famines and insect infestationsalready low-declined.

- Ratios of disasters to populations (or, disasters per million of population) also rose -from 0.35 to 0.47 -over the period in question. Corresponding ratios of floods and droughts rose while the values for other disasters changed little.

- Total deaths due to disasters rose sharply in the second sub-period, faster than the increase in the number of disasters.

\footnotetext{
${ }^{13}$ A difficulty is that conversion of changes in capital stock to income flows should take into account predisaster capacity utilization, depreciation of capital stock and efficiency of replacement assets (Andersen, 2005).

${ }^{14}$ For a disaggregated analysis by type of disaster (i.e. whether hydro-meteorological or geophysical), see Annex 2.
} 
- Consequently, deaths per disaster rose from 263 to 306-an increase of over 16 per cent. Also deaths per million of population rose from 92 to 144-an increase of about 57 per cent.

- Among the deadliest were volcanoes and earthquakes (per disaster) during 1985-1994. Both became less deadly in the next decade. Using a different criterion (deaths per million of population), the deadliest were windstorms and earthquakes during 1985-94. Both became less deadly during the next decade. By contrast, there was a sharp rise in the deadliness of wave surges and famines. So, while the aggregate of disasters became deadlier on different criteria, some disasters did on a specific criterion.

Summing up, and subject to the caveat that the averages reported cannot be the basis of trends, frequencies of natural disasters rose and they became deadlier. Graphical illustrations using shorter periods are given below.

Figure 1: Total Number of Natural Disasters

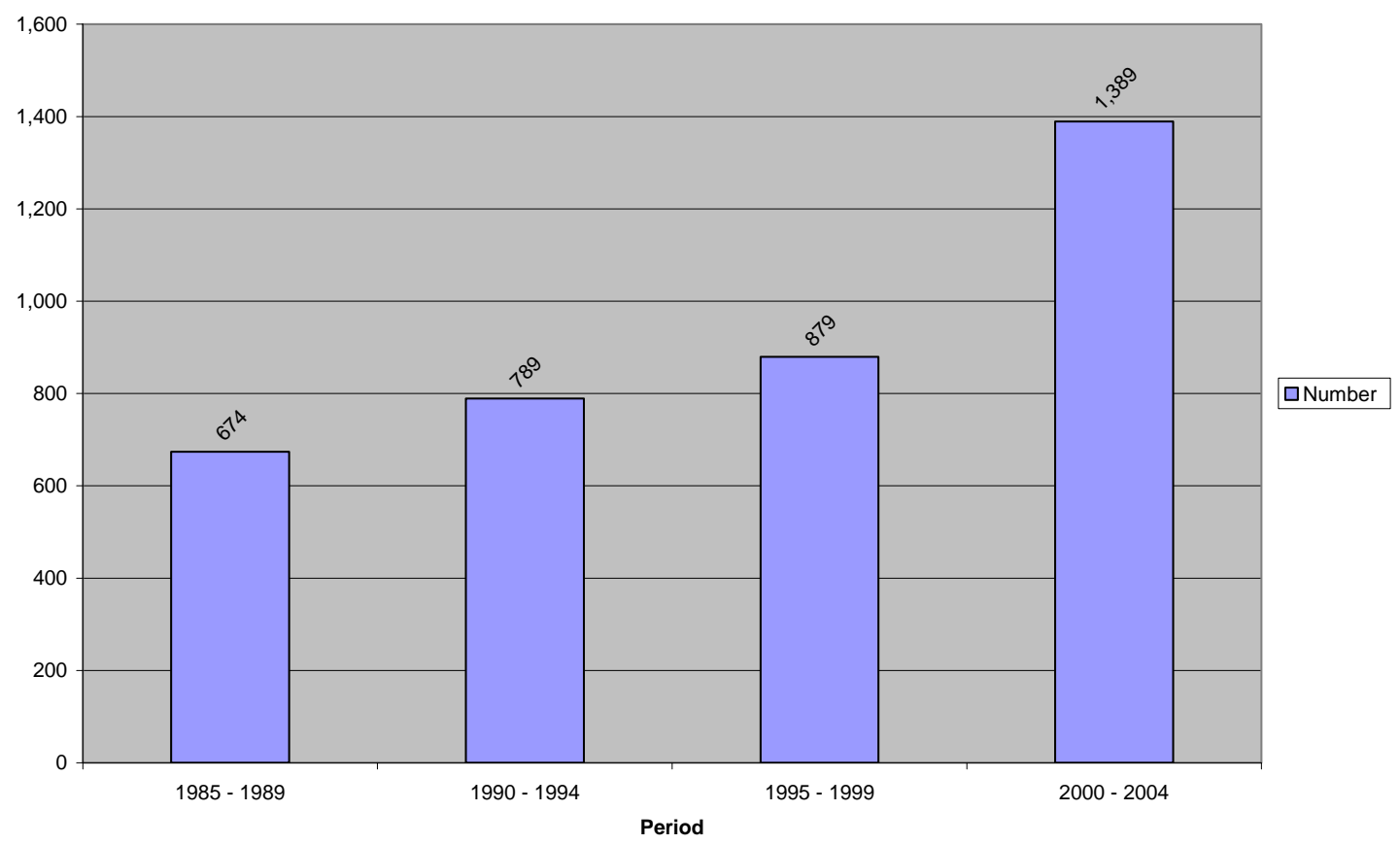

Source: Constructed from EM-DAT. 
Figure 2: Total Number of Deaths Due to Natural Disasters

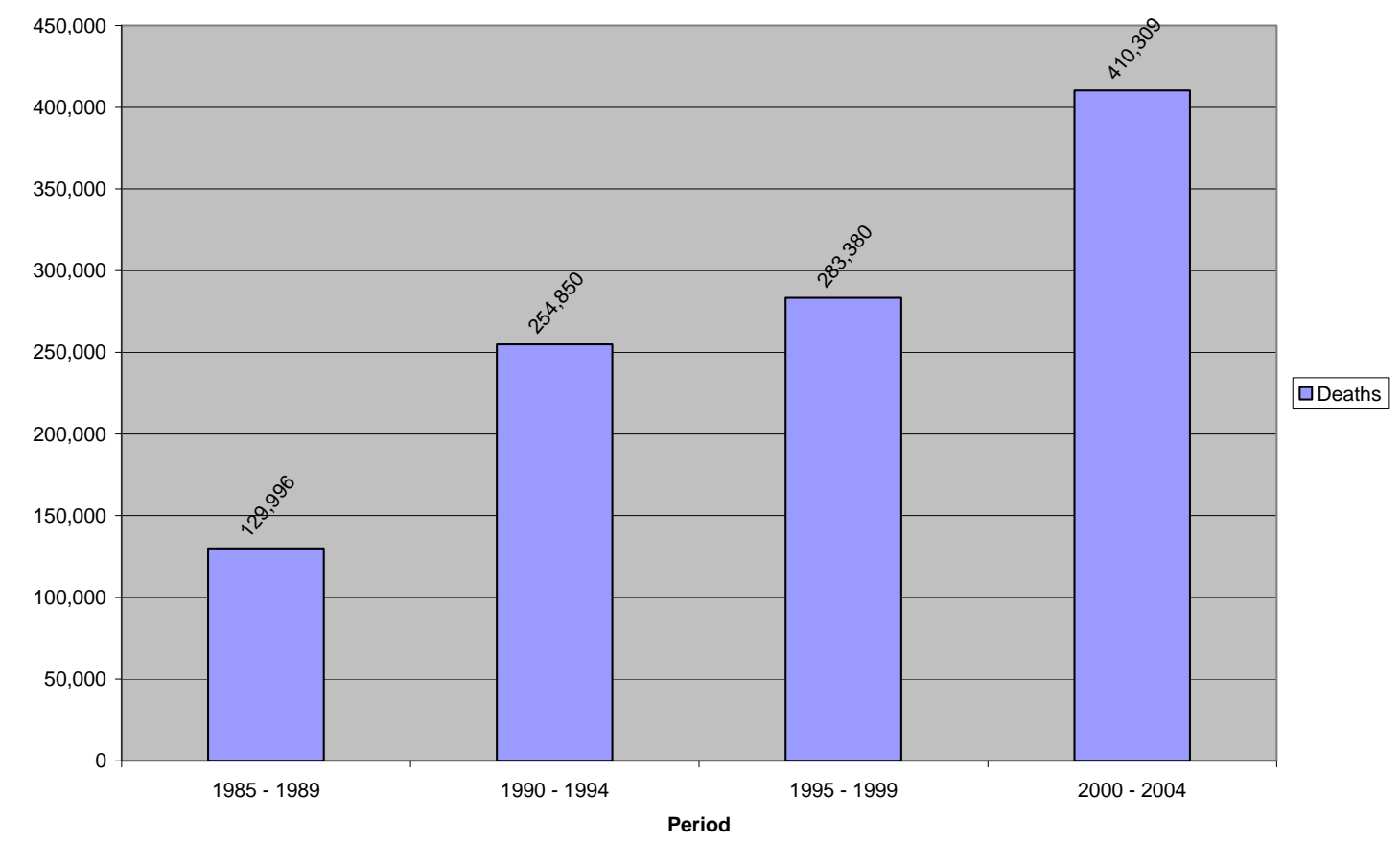

Source: Constructed from EM-DAT.

Fig 3: Total number of Deaths Per Disaster

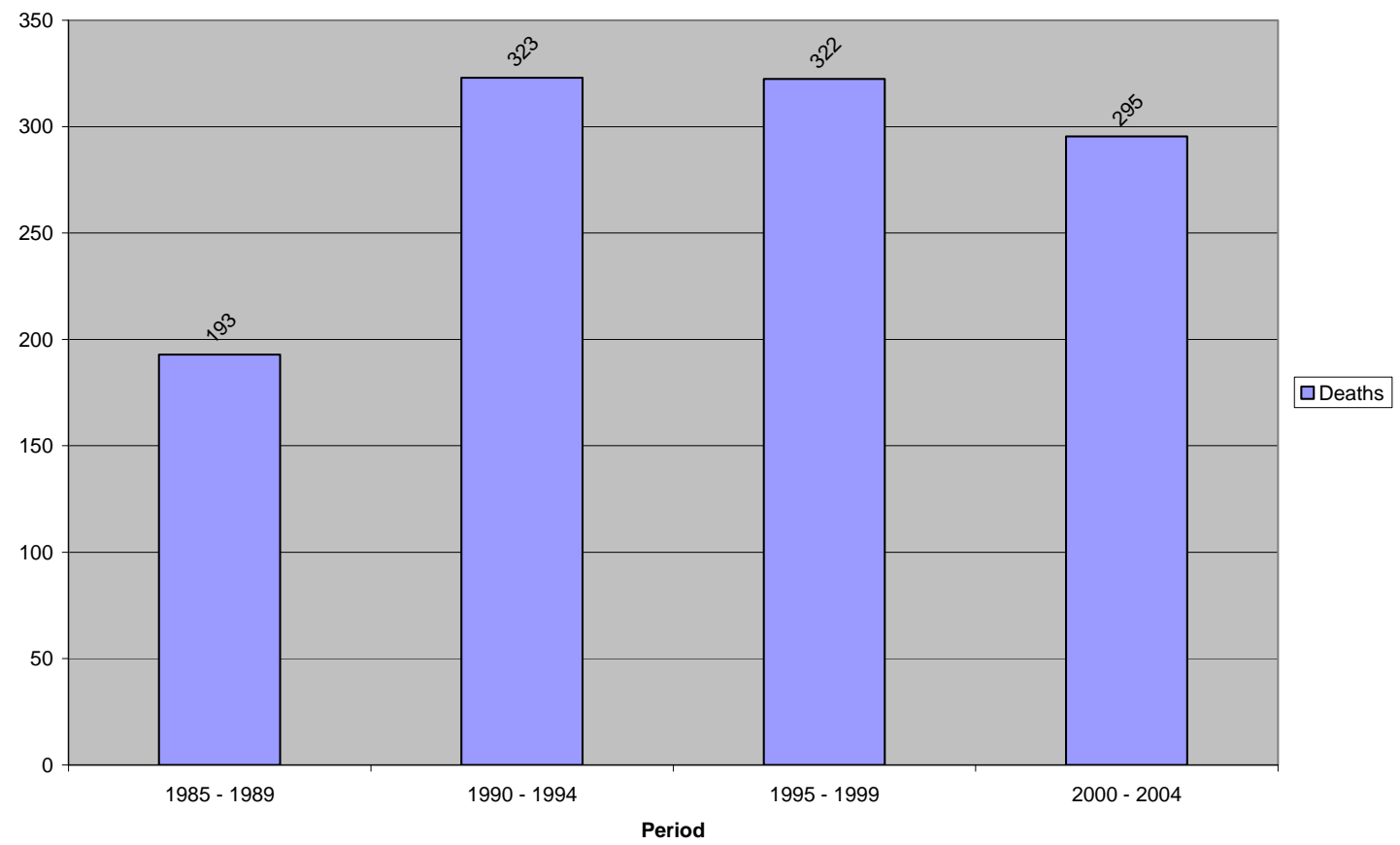

Source: Constructed from EM-DAT. 
Figure 4: Natural Disasters Per Million

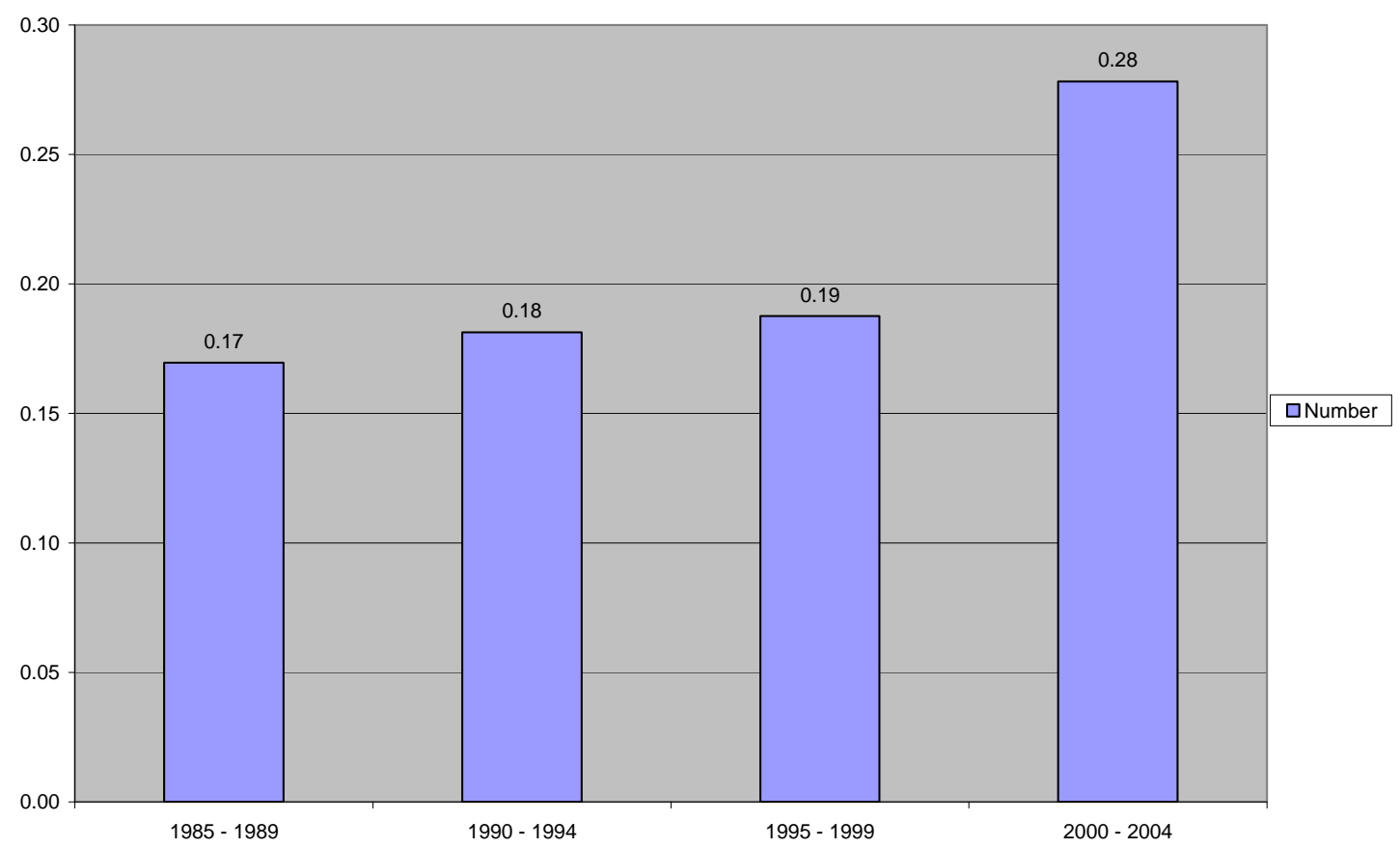

Source: Constructed from EM-DAT.

Figure 5: Deaths Due to Natural Disasters Per Million

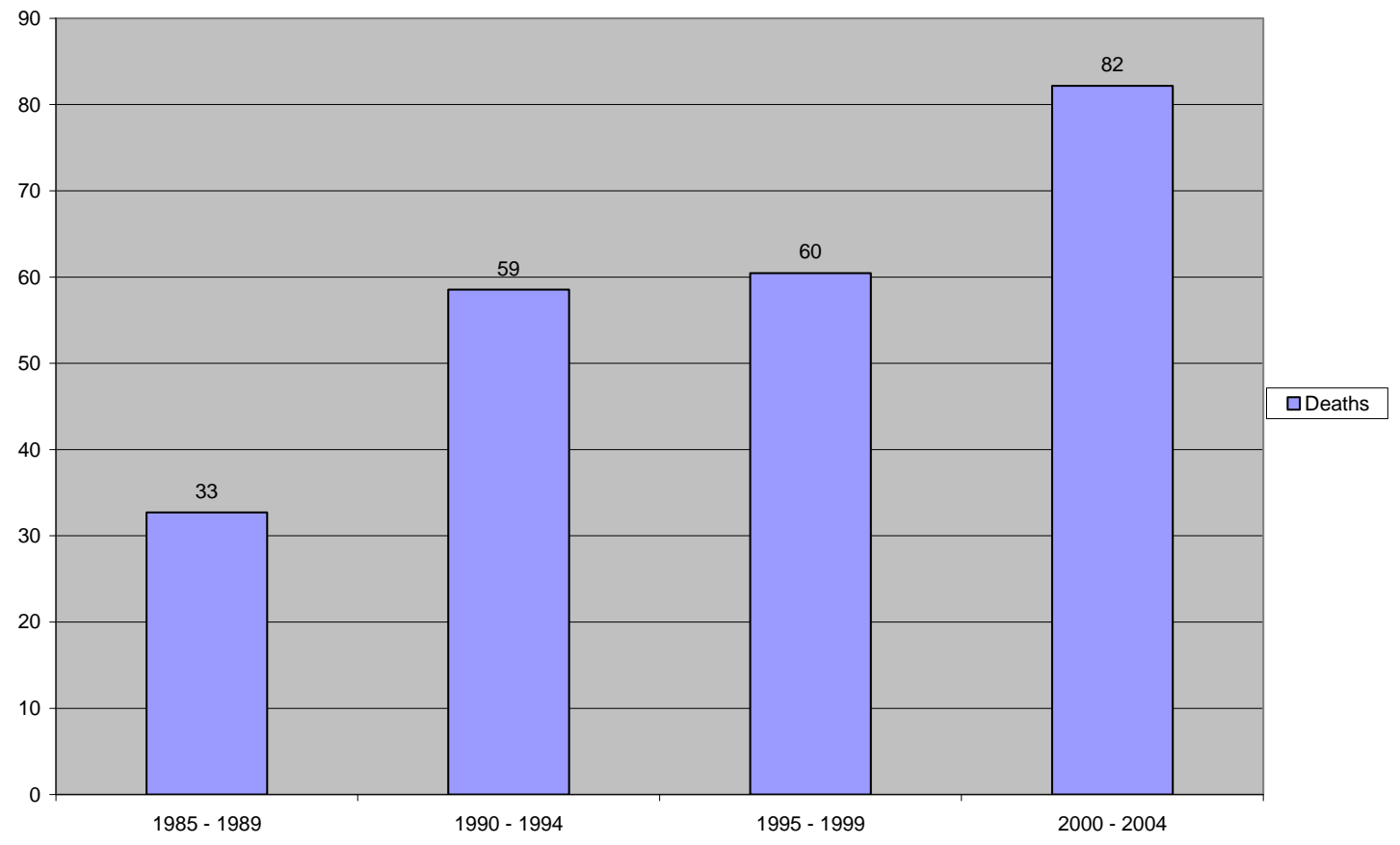

Source: Constructed from EM-DAT. 
Note that deaths per disaster were relatively high during the 1990s. Although there was a decline in deaths per disaster during 2000-2004, the deadliness of disasters was higher during this period relative to 1985-89. Since there was no change in the deadliness of disasters between 1990-94 and 1994-1999, the greater deadliness of disasters in 2000-04 relative to 1985-94 shows up in the higher average for the period 1995-2004. Deaths per million in 2000-04, however, were markedly higher than during earlier periods.

In Table 2, frequency distributions of natural disasters by region for two sub-periods, 198594 and 1995-2004, are given.

- The largest number of disasters occurred in East Asia and the Pacific, accounting for just under one third of the total during 1985-94. Latin America and the Caribbean was a close second, accounting for over 22 per cent of the natural disasters. The lowest numbers were recorded in Middle East and North Africa, and Europe and Central Asia, with relative frequencies between 6-8 per cent.

- There was a large increase in the number of disasters during the next decade, from 1463 to 2268. This is not surprising since each region recorded large increases.

- However, the relative frequencies changed slightly, with lower concentrations in South Asia, East Asia and the Pacific, and Latin America and the Caribbean. By contrast, the shares of Europe and Central Asia, and Sub-Saharan Africa rose.

To better understand the vulnerability of different regions to natural disasters, these are expressed per country and per million of population in each region. As may be noted from Table 3, vulnerability of regions to disasters differs depending on the ratio used.

- South Asia had the highest number of disasters per country during 1985-94 while Europe and Central Asia, and Sub-Saharan Africa had the lowest.

- All regions recorded large increases in the number of disasters in the next decade, with South Asia continuing to be the most vulnerable, followed by East Asia and the Pacific. Sub- Saharan Africa remained the least vulnerable, followed by Middle East and North Africa.

In the aggregate sample, there was a large increase in the number of disasters over the period in question, implying greater vulnerability.

When disasters are expressed per million of population, there are some striking changes. This is not surprising as populations of countries within a region vary.

Specifically, the most vulnerable was Latin America and the Caribbean during 1985-94, followed by Sub-Saharan Africa, and Middle East and North Africa. Latin America and the Caribbean remained the most vulnerable, followed by Sub-Saharan Africa, and Europe and Central Asia in 1995-04. On the other hand, South Asia, and East Asia and the Pacific remained the least vulnerable. 
Table 1 Different Types of Natural Disasters and Their Death Tolls

\begin{tabular}{|c|c|c|c|c|c|c|c|c|c|c|c|c|}
\hline \multirow[t]{2}{*}{ Disaster Type } & Frequency & Frequency & Deaths & Deaths & $\begin{array}{l}\text { Deaths } \\
\text { Million }\end{array}$ & per & $\begin{array}{l}\text { Deaths per } \\
\text { Million }\end{array}$ & $\begin{array}{l}\text { Deaths } \\
\text { Disaster }\end{array}$ & per & $\begin{array}{l}\text { Deaths per } \\
\text { Disaster }\end{array}$ & $\begin{array}{l}\text { Disasters per } \\
\text { million }\end{array}$ & $\begin{array}{l}\text { Disasters } \\
\text { per million }\end{array}$ \\
\hline & $\begin{array}{l}\text { 1985-94 } \\
\text { (\%) }\end{array}$ & $\begin{array}{l}\text { 1995-04 } \\
\text { (\%) }\end{array}$ & $\begin{array}{l}1985-94 \\
(\%)\end{array}$ & $\begin{array}{l}\text { 1995-04 } \\
\text { (\%) }\end{array}$ & $1985-94$ & & 1995-04 & $1985-94$ & & 1995-04 & $1985-94$ & $1995-04$ \\
\hline Floods & $\begin{array}{r}506 \\
(34.59)\end{array}$ & $\begin{array}{r}904 \\
(39.86)\end{array}$ & $\begin{array}{r}51383 \\
(13.35)\end{array}$ & $\begin{array}{r}89975 \\
(12.97)\end{array}$ & & 12 & 19 & & 102 & 100 & 0.12 & 0.19 \\
\hline Earthquakes & $\begin{array}{r}200 \\
(13.67)\end{array}$ & $\begin{array}{r}238 \\
(10.49)\end{array}$ & $\begin{array}{l}104124 \\
(27.06)\end{array}$ & $\begin{array}{r}69434 \\
(10.01)\end{array}$ & & 25 & 14 & & 521 & 292 & 0.05 & 0.05 \\
\hline Droughts & 96 & $\begin{array}{r}188 \\
(8.29)\end{array}$ & $\begin{array}{r}2911 \\
(0.76)\end{array}$ & $\begin{array}{r}1798 \\
(0.26)\end{array}$ & & 1 & 0.4 & & 30 & 10 & 0.02 & 0.04 \\
\hline Famines & $\begin{array}{r}25 \\
(1.71)\end{array}$ & $\begin{array}{r}32 \\
(1.41)\end{array}$ & $\begin{array}{r}8640 \\
(2.25)\end{array}$ & $\begin{array}{l}223644 \\
(32.24)\end{array}$ & & 2 & 46 & & 346 & 6989 & 0.01 & 0.01 \\
\hline Extreme Temperatures & $\begin{array}{r}42 \\
(2.87)\end{array}$ & $\begin{array}{r}112 \\
(4.94)\end{array}$ & $\begin{array}{r}3897 \\
(1.01)\end{array}$ & $\begin{array}{l}13721 \\
(1.98)\end{array}$ & & 1 & 3 & & 93 & 123 & 0.01 & 0.02 \\
\hline Insect Infestation & $\begin{array}{r}44 \\
(3.01)\end{array}$ & $\begin{array}{r}17 \\
(0.75)\end{array}$ & $\begin{array}{r}0 \\
0.00\end{array}$ & $\begin{array}{r}0 \\
0.00\end{array}$ & & 0.0 & 0.0 & & 0.0 & 0.0 & 0.01 & 0.004 \\
\hline Land Slide & $\begin{array}{r}117 \\
(8.00)\end{array}$ & $\begin{array}{r}169 \\
(7.45)\end{array}$ & $\begin{array}{r}7695 \\
(2.00)\end{array}$ & $\begin{array}{r}8236 \\
(1.19)\end{array}$ & & 2 & 2 & & 66 & 49 & 0.03 & 0.04 \\
\hline Wave Surge & $\begin{array}{r}4 \\
(0.27)\end{array}$ & $\begin{array}{r}21 \\
(0.93)\end{array}$ & $\begin{array}{r}111 \\
(0.03)\end{array}$ & $\begin{array}{l}228943 \\
(33.00)\end{array}$ & & 0.03 & 48 & & 28 & 10902 & 0.00 & 0.00 \\
\hline Volcano & $\begin{array}{r}35 \\
(2.39)\end{array}$ & $\begin{array}{r}38 \\
(1.68)\end{array}$ & $\begin{array}{l}24425 \\
(6.35)\end{array}$ & $\begin{array}{r}227 \\
(0.03)\end{array}$ & & 6 & 0.05 & & 698 & 6 & 0.01 & 0.01 \\
\hline Wild Fires & $\begin{array}{r}26 \\
(1.78)\end{array}$ & $\begin{array}{r}73 \\
(3.22)\end{array}$ & $\begin{array}{r}438 \\
(0.11)\end{array}$ & $\begin{array}{r}332 \\
(0.05)\end{array}$ & & 0 & 0 & & 17 & 5 & 0.01 & 0.02 \\
\hline Wind Storms & $\begin{array}{r}368 \\
(25.15)\end{array}$ & $\begin{array}{r}476 \\
(20.99)\end{array}$ & $\begin{array}{l}181222 \\
(47.09)\end{array}$ & $\begin{array}{l}57379 \\
(8.27)\end{array}$ & & 44 & 12 & & 492 & 121 & 0.09 & 0.10 \\
\hline Total & $\begin{array}{r}1463 \\
(100.00)\end{array}$ & $\begin{array}{r}2268 \\
(100.00)\end{array}$ & $\begin{array}{r}384846 \\
(100.00)\end{array}$ & $\begin{array}{r}693689 \\
(100.00)\end{array}$ & & 92 & 144 & & 263 & 306 & 0.35 & 0.47 \\
\hline
\end{tabular}


Table 2

Frequency Distributions of Natural Disasters by Region

\begin{tabular}{|l|c|c|c|c|}
\hline Region & $\begin{array}{c}\text { Number of } \\
\text { Disasters } \\
\text { in 1985-94 }\end{array}$ & $\begin{array}{c}\text { Number of } \\
\text { Disasters in } \\
1995-2004\end{array}$ & $\begin{array}{c}\text { Relative Frequency } \\
\text { of Disasters } \\
(1985-94) \text { in \% }\end{array}$ & $\begin{array}{c}\text { Relative Frequency } \\
\text { of Disasters } \\
\text { (1995-2004) in \% }\end{array}$ \\
\hline $\begin{array}{l}\text { Latin America } \\
\text { and the Caribbean }\end{array}$ & 326 & 499 & 22.28 & 22.0 \\
\hline South Asia & 249 & 327 & 17.02 & 29.06 \\
\hline $\begin{array}{l}\text { East Asia and the } \\
\text { Pacific }\end{array}$ & 465 & 659 & 7.93 & 11.90 \\
\hline $\begin{array}{l}\text { Europe and } \\
\text { Central Asia }\end{array}$ & 116 & 270 & 6.49 & 6.39 \\
\hline $\begin{array}{l}\text { Middle East and } \\
\text { North Africa }\end{array}$ & 212 & 368 & 14.49 & 16.23 \\
\hline $\begin{array}{l}\text { Sub-Saharan } \\
\text { Africa }\end{array}$ & 1463 & 2268 & 100 & 100 \\
\hline Total & 95 & & & 78 \\
\hline
\end{tabular}

Calculations based on EM-DAT. Note that rich OECD and non-OECD countries are excluded.

Table 3

Number of Natural Disasters by Region

\begin{tabular}{|l|c|c|c|c|}
\hline Region & $\begin{array}{c}\text { Number of } \\
\text { Disasters in } \\
1985-94 \\
\text { (per country) }\end{array}$ & $\begin{array}{c}\text { Number of } \\
\text { Disasters in } \\
1995-2004 \\
\text { (per country) }\end{array}$ & $\begin{array}{c}\text { Number of Disasters } \\
\text { in } \\
1985-94 \\
\text { (per million) }\end{array}$ & $\begin{array}{c}\text { Number of Disasters } \\
\text { in } \\
1995-2004 \\
\text { (per million) }\end{array}$ \\
\hline $\begin{array}{l}\text { Latin America } \\
\text { and the Caribbean }\end{array}$ & 13.58 & 20.79 & 0.77 & 1.0 \\
\hline South Asia & 35.57 & 46.71 & 0.23 & 0.25 \\
\hline $\begin{array}{l}\text { East Asia and the } \\
\text { Pacific }\end{array}$ & 24.47 & 34.68 & 0.29 & 0.37 \\
\hline $\begin{array}{l}\text { Europe and } \\
\text { Central Asia }\end{array}$ & 7.25 & 16.88 & 0.28 & 0.65 \\
\hline $\begin{array}{l}\text { Middle East and } \\
\text { North Africa }\end{array}$ & 8.64 & 13.18 & 0.44 & 0.66 \\
\hline $\begin{array}{l}\text { Sub-Saharan } \\
\text { Africa }\end{array}$ & 7.57 & 13.14 & 0.49 & 0.47 \\
\hline Total & 13.93 & 21.60 & 0.35 & 0.56 \\
\hline
\end{tabular}

Calculations based on EM-DAT. Note that rich OECD and non-OECD countries are excluded. 
All regions witnessed a rising frequency of disasters-using either ratio- but the increase in disasters per million was relatively small in South Asia. As a result, the aggregate sample also recorded an increase.

Another classification based on per capita income (based on the World Bank classification) yields somewhat surprising results. ${ }^{15}$

As may be seen from Table 4, the highest frequency of disasters occurred in Lower Middle Income countries during 1985-94, followed by Low Income countries. These two groups accounted for 90 per cent of the disasters recorded in the sample. Although (absolute) frequencies rose sharply in both groups in the following decade, their (combined) share decreased slightly.

Table 4

Number of Natural Disasters by Income Groups

\begin{tabular}{|l|c|c|c|c|}
\hline $\begin{array}{l}\text { Grouping by } \\
\text { Income }\end{array}$ & $\begin{array}{c}\text { Number of } \\
\text { Disasters in } \\
1985-94\end{array}$ & $\begin{array}{c}\text { Number of } \\
\text { Disasters in } \\
1995-2004\end{array}$ & $\begin{array}{c}\text { Relative Frequency } \\
\text { of Disasters } \\
(1985-94) \text { in \% }\end{array}$ & $\begin{array}{c}\text { Relative Frequency } \\
\text { of Disasters } \\
(1995-2004) \text { in \% }\end{array}$ \\
\hline Low Income & 544 & 871 & 37.18 & 38.40 \\
\hline $\begin{array}{l}\text { Lower Middle } \\
\text { Income }\end{array}$ & 774 & 1141 & 52.90 & 50.31 \\
\hline $\begin{array}{l}\text { Upper Middle } \\
\text { Income }\end{array}$ & 145 & 256 & 9.91 & 11.29 \\
\hline Total & 1463 & 2268 & 100 & 100 \\
\hline
\end{tabular}

Calculations based on EM-DAT. Note that rich OECD and non-OECD countries are excluded.

In Table 5, disasters are divided by number of countries in an income group and by population.

Table 5

Ratios of Natural Disasters by Income Groups

\begin{tabular}{|l|c|c|c|c|}
\hline $\begin{array}{l}\text { Grouping by } \\
\text { Income }\end{array}$ & $\begin{array}{c}\text { Number of } \\
\text { Disasters in 1985- } \\
94 \text { (per country) }\end{array}$ & $\begin{array}{c}\text { Number of } \\
\text { Disasters in 1995- } \\
\text { 2004 (per country) }\end{array}$ & $\begin{array}{c}\text { Number of } \\
\text { Disasters in 1985- } \\
94 \text { (per million) }\end{array}$ & $\begin{array}{c}\text { Number of Disasters } \\
\text { in 1995-2004 } \\
\text { (per million) }\end{array}$ \\
\hline Low Income & 11.83 & 18.93 & 0.32 & 0.42 \\
\hline $\begin{array}{l}\text { Lower Middle } \\
\text { Income }\end{array}$ & 19.85 & 29.26 & 0.35 & 0.46 \\
\hline $\begin{array}{l}\text { Upper Middle } \\
\text { Income }\end{array}$ & 7.25 & 12.80 & 0.59 & 0.90 \\
\hline Total & 13.93 & 21.60 & 0.35 & 0.47 \\
\hline
\end{tabular}

Calculations based on EM-DAT. Note that rich OECD and non-OECD countries are excluded.

${ }^{15}$ For details of the World Bank classification, see Table A.1.2 in Annex 1. 
Using the ratio of disasters per country, Lower Middle Income countries had the highest frequency during 1985-94, followed by Low Income countries. In each group, the frequency rose sharply, and, as a result, also in the aggregate sample during the following decade. When the ratio of disasters to population is used, Upper Middle Income countries recorded the largest number of disasters per million during 1985-94, followed by Lower Middle Income countries. In all groups-especially in the Upper Middle Income countries, as also in the aggregate sample- the vulnerability to natural disasters rose.

A graphical illustration of number of disasters by GDP per capita (PPP) in Figure 6 points to sharp spikes over the period 1985-2004, implying that the relationship between them varies greatly despite the heavy concentration of disasters in low income ranges. As reported later on the basis of regression analysis, income does not have a significant effect on frequency of natural disasters, controlling for the effects of other exogenous factors.

Figure 6: Frequency of Natural Disasters by GDP Per Capita during 1985-2004

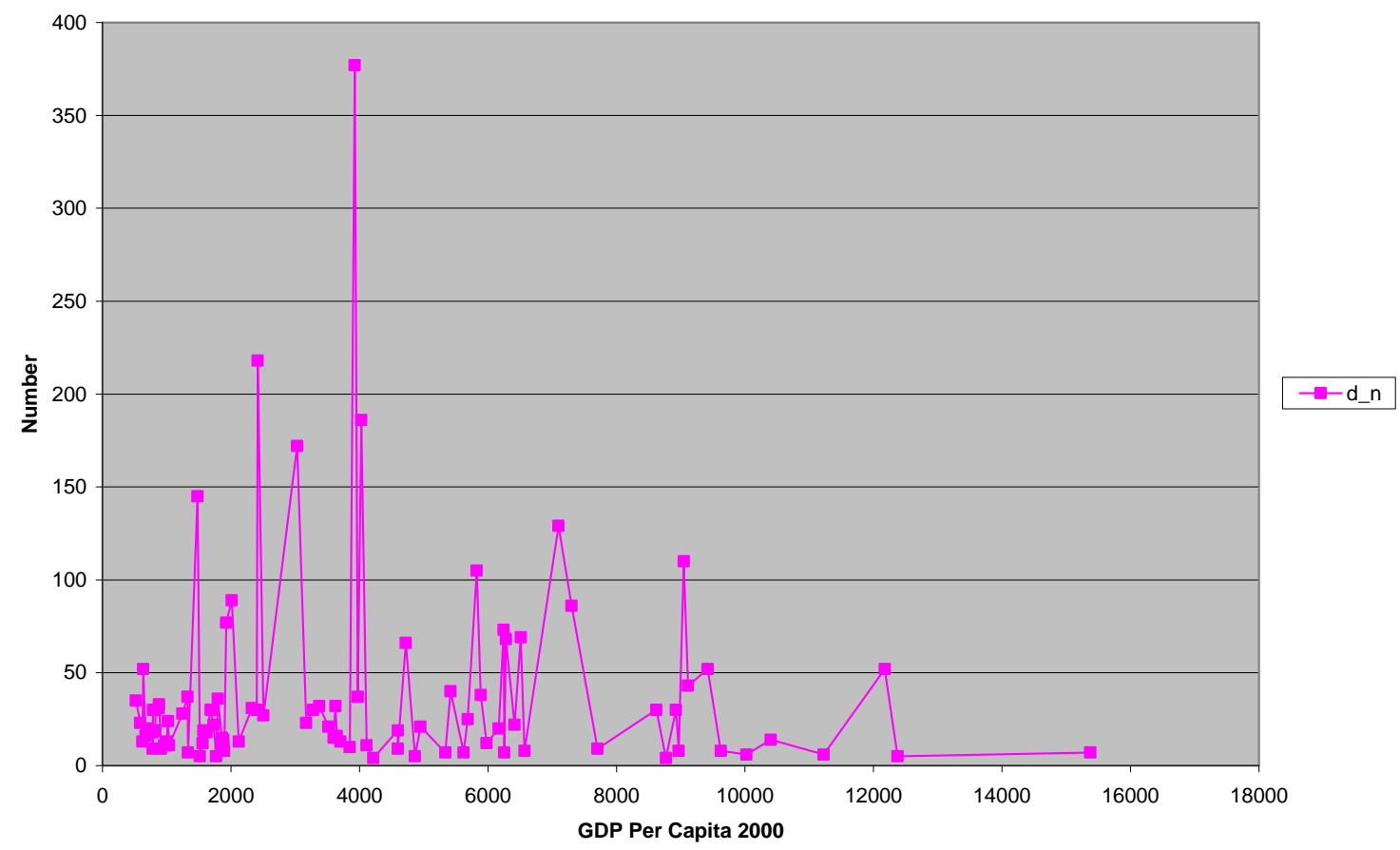

Source: Constructed from EM-DAT.

In brief, the frequency of disasters rose over the period 1995-2004, relative to 1985-94. However, there was no clear correspondence (i) either between the frequency of disasters and level of income, or (ii) between the relative frequency of disasters and level of income. Changes in the (absolute and relative frequencies of) disasters also followed a somewhat complex pattern. 
Figure 7: Natural Disasters Per Million by Income Group

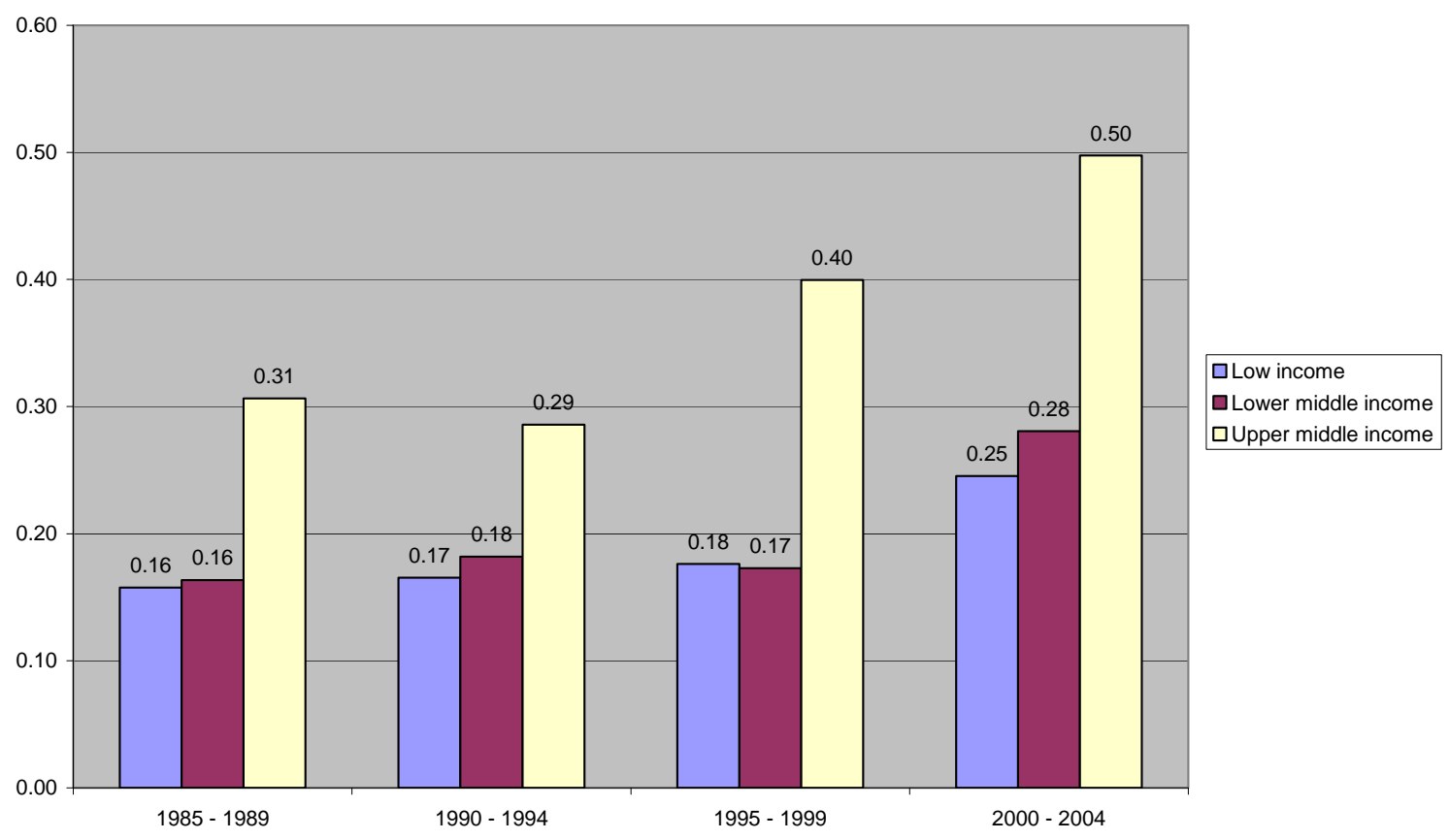

Source: Constructed from EM-DAT

Let us now examine the distribution of deaths associated with natural disasters over the period 1985-94, and changes in it in 1995-2004, using the regional and income classifications.

As shown in Table 6, more than half the deaths in 1985-94 occurred in South Asia, with nearly equal but considerably lower shares in Latin America and the Caribbean, East Asia and the Pacific, and Middle East and North Africa. In 1995-2004, a dramatic change occurred, as the share of East Asia and the Pacific climbed to about 63 per cent while that of South Asia dropped to less than one-fifth. The shares of Middle East and North Africa, Latin America and the Caribbean, Europe and Central Asia, and Sub-Saharan Africa also registered reductions.

If the ratio of deaths to disasters is used as an indicator of their deadliness, South Asia was ranked highest, followed by Middle East and North Africa, and Europe and Central Asia in 1985-94. In the following decade, East Asia was ranked highest, followed by South Asia, and Middle East and North Africa. East Asia and the Pacific also registered a large increase in the ratio in question while South Asia recorded a huge reduction. 
Table 6

Regional Distribution of Deaths Due to Natural Disasters

\begin{tabular}{|c|c|c|c|c|c|c|}
\hline Region & $\begin{array}{c}\text { Deaths in } \\
1985-94 \\
(\%)\end{array}$ & $\begin{array}{c}\text { Deaths in } \\
1995-04 \\
(\%)\end{array}$ & $\begin{array}{c}\text { Number of } \\
\text { Deaths Per } \\
\text { Disaster } \\
(1985-94)\end{array}$ & $\begin{array}{c}\text { Number of } \\
\text { Deaths Per } \\
\text { Disaster } \\
(1995-04)\end{array}$ & $\begin{array}{c}\text { Number of } \\
\text { Deaths in } \\
1985-94 \\
\text { (per million) }\end{array}$ & $\begin{array}{c}\text { Number of } \\
\text { Deaths in } \\
1995-04 \\
\text { (per million) }\end{array}$ \\
\hline $\begin{array}{l}\text { Latin America } \\
\text { and the } \\
\text { Caribbean }\end{array}$ & $\begin{array}{c}48016 \\
(12.48)\end{array}$ & $\begin{array}{l}66826 \\
(9.63)\end{array}$ & 147 & 134 & 114 & 136 \\
\hline South Asia & $\begin{array}{l}200357 \\
(52.06)\end{array}$ & $\begin{array}{l}132838 \\
(19.15)\end{array}$ & 805 & 406 & 181 & 102 \\
\hline $\begin{array}{l}\text { East Asia and } \\
\text { the Pacific }\end{array}$ & $\begin{array}{c}48210 \\
(12.53)\end{array}$ & $\begin{array}{l}436517 \\
(62.93)\end{array}$ & 104 & 662 & 30 & 245 \\
\hline $\begin{array}{l}\text { Europe and } \\
\text { Central Asia }\end{array}$ & $\begin{array}{l}30231 \\
(7.86)\end{array}$ & $\begin{array}{c}7804 \\
(1.12)\end{array}$ & 261 & 29 & 74 & 19 \\
\hline $\begin{array}{l}\text { Middle East } \\
\text { and North } \\
\text { Africa }\end{array}$ & $\begin{array}{c}44002 \\
(11.43)\end{array}$ & $\begin{array}{l}36789 \\
(5.30)\end{array}$ & 463 & 254 & 205 & 140 \\
\hline $\begin{array}{l}\text { Sub-Saharan } \\
\text { Africa }\end{array}$ & $\begin{array}{l}14030 \\
(3.65)\end{array}$ & $\begin{array}{l}12915 \\
(1.86)\end{array}$ & 66 & 35 & 32 & 23 \\
\hline Total & $\begin{array}{c}384846 \\
(100)\end{array}$ & $\begin{array}{c}693689 \\
(100)\end{array}$ & 263 & 306 & 92 & 144 \\
\hline
\end{tabular}

Calculations based on EM-DAT. Note that rich OECD and non-OECD countries are excluded.

Alternatively, deadliness of disasters could be expressed as deaths per million of population. The ranking changes, with Middle East and North Africa at the top, followed closely by South Asia in 1985-94. In the following decade, the deadliness of disasters was highest in East Asia and the Pacific, with Middle East and North Africa, and Latin America and the Caribbean tied closely for the second rank. But there was a more than moderate reduction in the deadliness of disasters in South Asia and Middle East and North Africa, among others. Figure 8 illustrates graphically these changes. Yet in the aggregate sample the disasters became deadlier. 
Figure 8: Deaths Per Million by Region

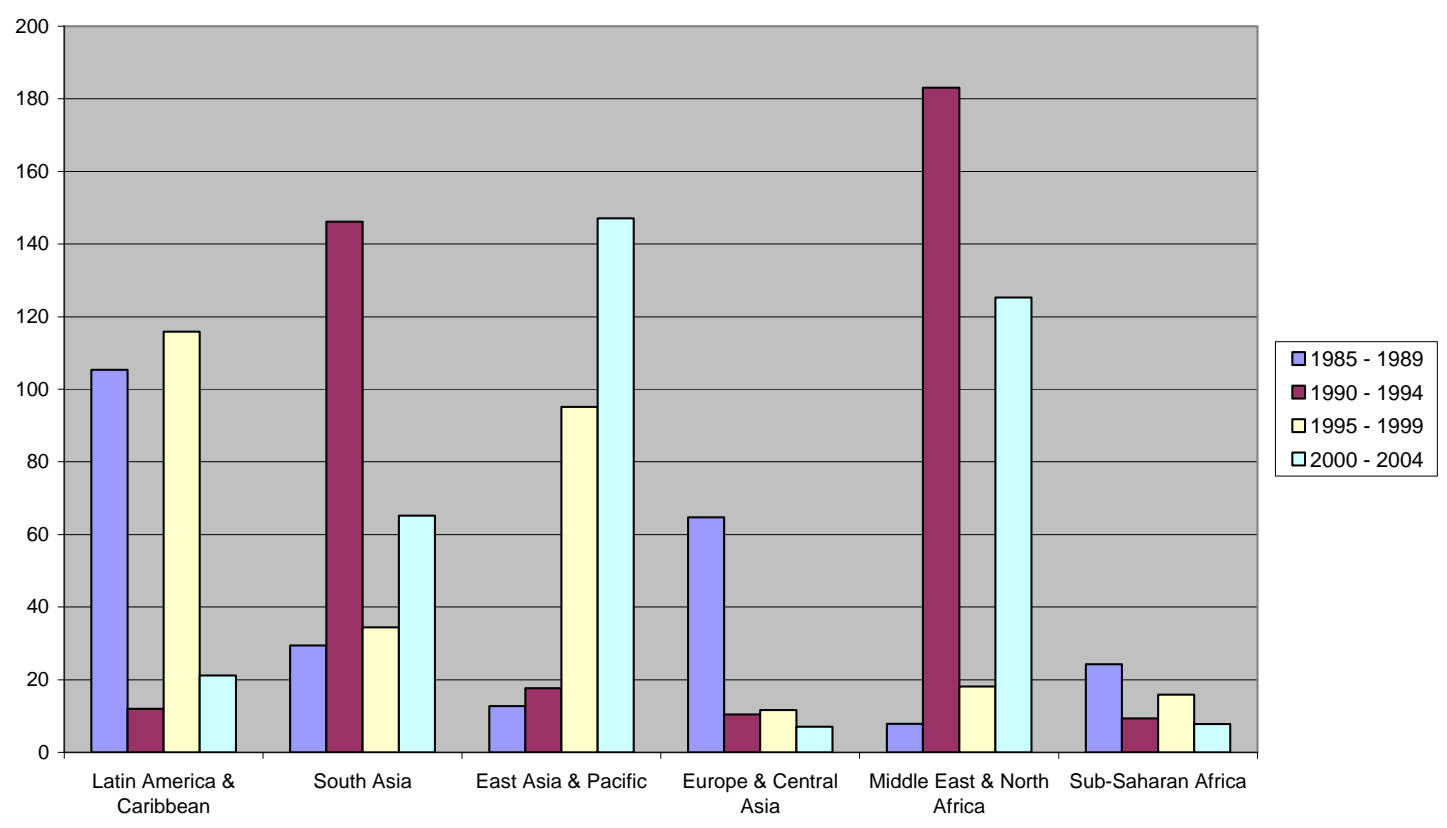

Source: Constructed from EM-DAT

The preceding analysis is repeated for income-groups of countries. The main findings are

- A vast majority of disaster-related deaths occurred in Low Income and Lower Middle Income countries (about 97 per cent of total deaths in 1985-94).

- Although there were large increases in deaths in the following decade, the combined share of these two income groups recorded a slight reduction (it fell to about 95 per cent).

- Ratio of deaths to disasters was highest in Low Income countries, followed by Lower Middle Income countries. Disasters, however, were about half as deadly in the latter. While the deadliness of disasters in Low Income countries reduced slightly in the next decade, it remained substantially higher than in other income groups.

- In the remaining two groups, there was a marked increase in the deadliness of disastersespecially in Lower Middle Income countries.

- Deaths per million reveal a similar pattern except that deadliness of disasters rose in all income groups in 1995-04. It is noteworthy that deadliness of disasters in Upper Middle Income countries rose two and a half times.

A graphical illustration is given in Figure 9. 
Table 7

Deadliness of Disasters by Income Group

\begin{tabular}{|l|c|c|c|c|c|c|}
\hline $\begin{array}{l}\text { Grouping by } \\
\text { Income }\end{array}$ & $\begin{array}{c}\text { Deaths in } \\
1985-94 \\
(\%)\end{array}$ & $\begin{array}{c}\text { Deaths in } \\
1995-04 \\
(\%)\end{array}$ & $\begin{array}{c}\text { Number of } \\
\text { Deaths Per } \\
\text { Disaster } \\
(1985-94)\end{array}$ & $\begin{array}{c}\text { Number of } \\
\text { Deaths Per } \\
\text { Disaster } \\
(1995-04)\end{array}$ & $\begin{array}{c}\text { Number of } \\
\text { Deaths in } \\
\text { 1985-94 (per } \\
\text { million) }\end{array}$ & $\begin{array}{c}\text { Number of } \\
\text { Deaths in } \\
1995-04 \\
\text { (per million) }\end{array}$ \\
\hline Low Income & $\begin{array}{c}222863 \\
(57.91)\end{array}$ & $\begin{array}{c}351214 \\
(50.63)\end{array}$ & 410 & 403 & 132 & 173 \\
\hline $\begin{array}{l}\text { Lower Middle } \\
\text { Income }\end{array}$ & $\begin{array}{c}149639 \\
(38.88)\end{array}$ & $\begin{array}{c}307439 \\
(44.32)\end{array}$ & 193 & 269 & 67 & 123 \\
\hline $\begin{array}{l}\text { Upper Middle } \\
\text { Income }\end{array}$ & $\begin{array}{c}12344 \\
(3.21)\end{array}$ & $\begin{array}{c}35036 \\
(5.05)\end{array}$ & 85 & 137 & 50 & 124 \\
\hline Total & $\begin{array}{c}384846 \\
(100)\end{array}$ & $\begin{array}{c}693689 \\
(100)\end{array}$ & 263 & 306 & 92 & 144 \\
\hline
\end{tabular}

Calculations based on EM-DAT. Note that rich OECD and non-OECD countries are excluded.

Figure 9: Deaths Per Million by Income Group

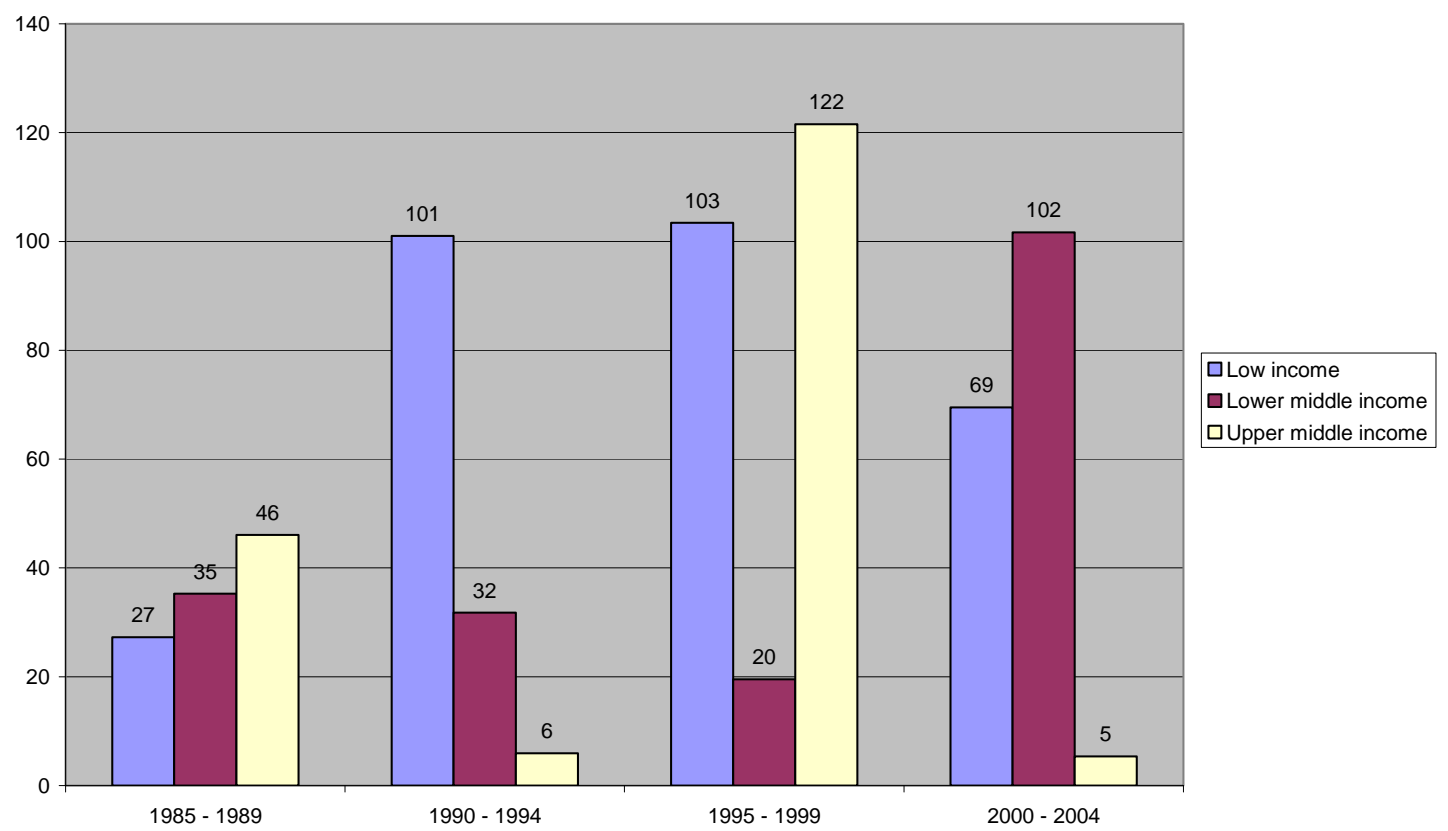

Source: Constructed from EM-DAT.

The preceding analysis points to an increase in the frequency of natural disasters as well as higher deaths. There were, however, some regional and income group contrasts that require more detailed investigation. But these averages are subject to the caveat that they cannot be interpreted as trends. 


\section{Determinants of Disasters and Their Deadliness}

\section{(a) Disasters}

Frequency of disasters is specified as a function of geophysical features of a country (e.g. degree of elevation, distance from a coast, size), its population density, level of development, and polity (as a measure of how democratic the regime is), log of lagged deaths (in 1970-79) and lagged number of disasters (i.e. in 1970-79). The lagged number of disasters is an instrument for disasters in 1980-2004. As IV estimation is used, (log of) deaths in the second equation are hypothesized to depend on all exogenous variables in the first equation (except natural disasters in 1970-79) and predicted frequency of disasters from the first equation ${ }^{16}$.

The structural equation of deaths is specified as:

$$
\log \text { of } \mathrm{D}_{\mathrm{i}}=\beta_{0}+\beta_{1} N D_{i}+\beta_{2} Z_{1 i}+u_{i}
$$

where $\mathrm{D}_{\mathrm{i}}$ denotes deaths due to natural disasters in country $\mathrm{i}$ in $1980-2004, N D_{i}$ refers to natural disasters during the same period, and $Z_{1 i}$ denotes a vector of exogenous variables (which vary by country). Exogenous variables include geo-physical characteristics of a country (whether land locked, area, population density, elevation, distance from a coast), socio-economic characteristics (ethnic fractionalization, per capita income level) and institutions (a measure of democracy). Number of disasters, $N D_{i}$, is supposed to be endogenous. So we need another equation-a reduced form- with number of disasters as the dependent variable.

$$
N D_{i}=\pi_{0}+\pi_{1} Z_{1 i}+\pi_{2} Z_{2 i}+v_{i}
$$

where, in addition to $Z_{1 i}$, the exogenous variables from the structural equation we have an instrument variable, $Z_{2}$. The instrument chosen is lagged natural disasters (in 1970-79). There is a caveat, however. If natural disasters are serially correlated, using lagged natural disasters as an identifying instrument for natural disasters (in 80-94) does not fully control for unobserved heterogeneity across countries. A key identification condition is $\pi_{2}=0$, among others. ${ }^{17}$ Accordingly, IV estimation is used.

Since hardly any country escaped a natural disaster during 1980-2004, use of IV procedure is not problematic, with adjustment of standard errors for heteroscedasticity. Several specifications were experimented with to avoid omitted variable bias. A selection of the results is given below. ${ }^{18}$

The main findings from Table 9 are:

Number of natural disasters varied negatively with whether a country was landlocked, or, frequency of disasters was lower in landlocked countries. The longer the distance from a sea coast, the higher was the frequency of natural disasters. Frequency of disasters varied with

\footnotetext{
${ }^{16}$ For convenience of exposition, log of deaths and deaths are used synonymously.

${ }^{17}$ For a clear and comprehensive exposition of identification conditions, see Baum (2006).

${ }^{18}$ Supplementary results based on other specifications are available on request.
} 
the (lagged) frequency during 1970-80.Or, countries that were more prone to disasters in 1970-79 remained so during 1980-2004. If (lagged) deaths in 1970-79 are treated as a measure of severity of disasters, our result implies that countries that were prone to severe disasters were also more prone to disasters in subsequent years in general.

The fact that lagged natural disasters influenced significantly occurrence of disasters in 19802004 suggests that the former is a relevant instrument. This is also corroborated by the significant F-value.

The Cragg-Donald Wald F statistic and Kleibergen -Paap Wald rk F statistic reject the null of weak identification.

\section{Table 9}

Occurrence of Natural Disasters in 1980-2004

\begin{tabular}{|c|c|c|c|}
\hline \multicolumn{4}{|c|}{ No. of observations $=86$} \\
\hline \multicolumn{4}{|c|}{$F(13,72)=15.87$} \\
\hline \multicolumn{4}{|c|}{ Prob. $>F=0.0000$} \\
\hline Number of natural disasters during 1980-2004 & & Toefficieı & \\
\hline Landlocked & -22.889 & $(-1.8)$ & $*$ \\
\hline Medium $^{1}$ & 1.941 & $(0.24)$ & - \\
\hline Large & 13.544 & $(1.15)$ & - \\
\hline Mean elevation (metres above sea level) & 0.011 & $(1.22)$ & - \\
\hline Ethnic & -34.498 & $(-1.41)$ & - \\
\hline Persons/ km² & 0.021 & $(0.89)$ & - \\
\hline Persons/ km² - Squared & -0.000 & $(-0.56)$ & - \\
\hline Income Dummy - Lower Middle Income ${ }^{2}$ & 8.983 & $(0.91)$ & - \\
\hline Income Dummy - Upper Middle Income & 7.605 & $(0.55)$ & - \\
\hline Log of deaths from disasters during 1970-79 & 4.939 & $(2.02)$ & $* *$ \\
\hline Polity Mean for years $1985-94$ (range -10 to 10 ) & -0.902 & $(-0.87)$ & - \\
\hline Mean distance to nearest coastline $(\mathrm{km})$ & 0.035 & $(2.15)$ & $* *$ \\
\hline Number of natural disasters during 1970-1979 & 2.821 & $(5.4)$ & $* * *$ \\
\hline Constant & -9.544 & $(-0.56)$ & - \\
\hline $\begin{array}{l}\text { F test of excluded instruments: } \\
F(1,72) \\
\text { Prob }>F=0.0000\end{array}$ & 29.14 & & \\
\hline Cragg-Donald Wald F statistic & 31.22 & & \\
\hline Kleibergen-Paap Wald rk F statistic & 29.14 & & \\
\hline
\end{tabular}

1. The area dummies are as follows:

Small $=0-200000 \mathrm{~km}^{2}$ (Omitted), Medium $=200000-750000 \mathrm{~km}^{2}$, Large $=>750000 \mathrm{~km}^{2}$

2. Omitted income group is Low Income; *** Denote significance at the 1 per cent level, ** at the 5 per cent level, and ${ }^{*}$ at the 1 per cent level, respectively. 
Analysis of residuals of total disasters during 1980-2004 suggests that these did not bear any relationship to exposure to media-in particular, availability of newspapers per 1000 people during 1997-2000. It is surmised therefore that disaster reporting was not more accurate in countries better exposed to mass media ${ }^{19}$.

\section{(b) Mortalities}

A selection of results on the determinants of deaths from disasters is given in Table 10. The main findings are the following:

Table 10

Determinants of Mortality

Second Stage Regressions

\begin{tabular}{|c|c|c|c|}
\hline \multicolumn{4}{|c|}{ No. of observations $=86$} \\
\hline \multicolumn{4}{|c|}{$F(13,72)=10.03$} \\
\hline \multicolumn{4}{|c|}{ Prob. $>F=0.0000$} \\
\hline Number of natural disasters during 1980-2004 & Coefficient & & Significance \\
\hline Predicted natural disasters during 1980-2004 & 0.010 & $(1.91)$ & * \\
\hline Landlocked & -0.660 & $(-0.96)$ & - \\
\hline Medium $^{1}$ & 0.456 & $(1.01)$ & - \\
\hline Large & 1.547 & (2.39) & $* *$ \\
\hline Mean elevation (metres above sea level) & 0.000 & $(0.51)$ & - \\
\hline Ethnic & -1.538 & $(-1.32)$ & - \\
\hline Persons/ km² & -0.001 & $(-0.81)$ & - \\
\hline Persons/ km²- Squared & 0.000 & $(1.13)$ & - \\
\hline Income Dummy - Lower Middle Income ${ }^{2}$ & -1.124 & $(-2.26)$ & $* *$ \\
\hline Income Dummy - Upper Middle Income & -2.029 & $(-2.79)$ & $* * *$ \\
\hline Log of deaths from disasters during 1970-79 & 0.279 & $(3.01)$ & $* * *$ \\
\hline Polity Mean for years $1985-94$ (range -10 to 10 ) & 0.032 & $(0.84)$ & - \\
\hline Mean distance to nearest coastline $(\mathrm{km})$ & -0.000 & $(-0.12)$ & - \\
\hline Constant & 6.513 & (6.34) & $* * *$ \\
\hline
\end{tabular}

1 The area dummies are as follows:

Small $=0-200000 \mathrm{~km}^{2}$ (Omitted), Medium $=200000-750000 \mathrm{~km}^{2}$ and Large $>750000 \mathrm{~km}^{2}$

2. Omitted income group is Low Income.

3. *** Denote significance at the 1 per cent level, ** at the 5 per cent level, and * at the 1 per cent level, respectively.

Large $=>750000 \mathrm{~km} 2$

\footnotetext{
${ }^{19}$ Details are given in Annex 3. Note that this variable could not be incorporated in the regressions because of the smallness of the sample.
} 
Deaths vary with the size of a country -highest among the largest relative to the smallest. Somewhat surprisingly, deaths are unrelated to population density. Higher income levels are associated with lower deaths. Deaths are unrelated to ethnic diversity that could impede collective action. ${ }^{20}$ (Predicted) frequency of disaster has a positive effect on deaths. As (lagged) deaths, a measure of severity of disasters in 1970-79, are related to disasters, there is an indirect effect of (lagged) deaths through this channel on deaths in 1980-2004. In addition, there is a direct effect of (lagged) deaths during this period. Degree of democracy (defined as the difference between democracy and autocracy, Polity 1) does not have a significant coefficient. ${ }^{21}$ As discussed later, this flies in the face of findings from other studies that democracy makes a difference. ${ }^{22}$

As in the case of occurrence of disasters, the residuals do not indicate more accurate reporting of deaths in countries better exposed to mass media. ${ }^{23}$

\section{Discussion}

As detailed simulations of disaster risk prevention and mitigation are not feasible, a broadbrush treatment based on key elasticities is given below. We consider two basic scenarios: the first entails different assumptions about learning from past disasters and fatalities, and the second assumes a reduction in the number of countries moving up into higher ranges of income. ${ }^{24}$ One aspect of learning is whether there is reduction in number of disasters relative to lagged disasters in 1970-79. As our results show, countries with 5 per cent higher disasters in 1970-79 were vulnerable to about 2 per cent higher frequency of disasters in 1980-2004. This implies that whatever the prevention measures their effectiveness was far from adequate. If we interpret lagged fatalities as an indicator of severity of disasters, the positive elasticity of disasters to this variable (0.10) further corroborates limited learning, as frequency of disasters was higher in countries that suffered severe disasters in 1970-79.

${ }^{20}$ In different specifications, measures of linguistic and religious fragmentation were used. No significant results were obtained. Details will be furnished on request. For a detailed exposition of why ethnic fractionalization matters a great deal for growth and quality of government, see Alesina et al. (2003).

${ }^{21}$ (a) For details of measurement of polity, see Polity IV project, administered by the Centre for International Development and Conflict Management, University of Maryland. (b) That freedom of the press is an important factor in averting famines in India is persuasively argued by Dreze and Sen (1989).

${ }^{22}$ We also considered a variable designated as New State but it did not yield a significant result. This is a measure of colonization. The more recent is the timing of independence, the longer is the spell of colonization. But, more generally, the more recent the timing of independence, the more daunting is the challenge of nation-building. For details, see Gallup et al. (1999).

${ }^{23}$ Details are given in Annex 3.

${ }^{24}$ Cole et al. (2012) analysis confirms that government responsiveness is greater when the severity of the crisis is greater. Also, voters punish incumbent politicians for crises beyond their control (a severe drought caused by monsoon failure). While voters also reward politicians for responding well to climatic events, they do not compensate them sufficiently for their "bad luck”. There is thus a robust confirmation of Sen's $(1998,1999)$ conjecture that democracies are better at responding to more salient catastrophes. However, what undermines the plausibility of Cole et al. (2012) is its failure to account for the fact that drought relief seldom reaches the victims or a fraction reaches them because of huge leakages. Besides, an analysis grounded in inter-temporal rationality of voters that allows for learning over time-whether, for example, mandates and programmes announced were implemented satisfactorily-would have been more plausible. Nevertheless, a link between democracy and fewer deaths through electoral incentives is established. 
Turning to the deaths, their elasticity to (predicted) disasters was high ( 0.47 per cent). Or, a 5 per cent higher frequency of disasters was associated with 2.35 per cent higher mortality. So the death toll of disasters was high. Countries that recorded high deaths in 1970-79 also recorded higher deaths in 1980-2004 (the elasticity being about 0.28 per cent). So countries with 5 per cent higher lagged deaths recorded 1.4 per cent higher deaths. In addition, there is an indirect effect of lagged deaths through higher frequency of natural disasters leading to still higher deaths. However, the indirect elasticity is (relatively) small. (Absolute) elastcities of deaths to income levels are high. Note that these elasticities denote deaths in Lower Middle Income and Upper Middle Income countries with respect to Low Income countries. The fact that these elasticities are negative implies that they are lower than in Low Income countries. So let us consider the counterfactual of a higher number of countries in the Lower Middle Income group (as a result of Low Income countries moving up into the next higher group). Here the emphasis shifts to resources for enhancing disaster prevention and mitigation of fatalities as well as a stronger preference for safety. So if the number of countries in the Lower Middle Income group increases by 5 per cent, the fatalities would reduce by over 2 per cent. If those in the Upper Middle Income group increase by 5 per cent, the deaths are likely to decrease by a little over 1.5 per cent. While these results point to the important role of income in preventing deaths, it is plausible that the effect of income reduces at higher levels. ${ }^{25}$

Somewhat surprising is the absence of a significant relationship between democracy and mortality. This is intriguing as good institutions (parliaments, media and communities) are frequently associated with lower damages and deaths, since they permit public oversight. But these institutions function differently across countries even if they have similar legal authority and responsibility. Storm damage, for example, is more severe in Haiti than in adjoining Dominican Republic. Haiti's institutions and communities have suffered from long decades of misrule. Often, institutions are linked to democracy but what matters more is political competition (World Bank, 2010).

Table 11

Reduction in Disasters and Mortality

\begin{tabular}{|l|l|}
\hline \multicolumn{1}{|c|}{ First Stage Regression } & \\
\hline Number of natural disasters during 1980-2004 & Elasticity \\
\hline Deaths from disasters during 1970-79 & 0.105 \\
\hline Mean distance to nearest coastline (km) & 0.344 \\
\hline Number of natural disasters during 1970-1979 & 0.392 \\
\hline \multicolumn{1}{|c|}{ Second Stage Regression } & \\
\hline Log of deaths from disasters during 1980-2004 & \\
\hline (Predicted) natural disasters during 1980-2004 & 0.471 \\
\hline Income Dummy - Lower Middle Income & -0.405 \\
\hline Income Dummy - Upper Middle Income & -0.307 \\
\hline Deaths from disasters during 1970-79 & 0.279 \\
\hline
\end{tabular}

1. The indirect effect of lagged deaths is traced through its effect on frequency of disasters and then on deaths in 1980-2004.

${ }^{25}$ See, for example, Toya and Skidmore (2007) which confirms an inverse relationship between numbers killed and income. 
In sum, income (and by implication its growth) matter a great deal in averting disaster-related deaths. While learning from past experience takes diverse forms and magnitudes, our assessment suggests that it has been far from adequate. Lagged disasters are associated with higher frequency of disasters which in turn cause higher fatalities. Also, the direct effect of lagged deaths on subsequent deaths is high, further pointing to limited learning from past experience of severe disasters. While institutions matter, our analysis was not detailed enough to validate their role.

\section{Catastrophic Risks, Insurance and Reconstruction}

An important point is that, while natural hazards cannot be controlled, they become disasters because of failures of communities, governments and donors. In that sense, disasters are man-made. A case in point is droughts turning into famines. So a general observation on greater vulnerability to natural disasters in the last three decades is that, whatever the role of climate change in the greater frequency and severity of natural hazards (e.g. droughts, floods), and growth of physical assets and human settlements in areas more exposed to such hazards, their effects are compounded by government and community failures. ${ }^{26}$ In this context, it may be emphasized that growing urbanization has compounded the problem as even a minor event can cause enormous damage in a heavily populated area. The proportion of people in developing countries who live in cities has doubled since 1960. More than 40 per cent now live in urban areas, and it is projected to rise to 55 per cent by 2030. Nearly half of these cities are subject to extreme weather events ${ }^{27}$ (Freeman et al. 2003, World Bank, 2010, The Economist, January $14^{\text {th }}$, 2012).

Let us now turn to strategic considerations and priorities in disaster risk prevention and mitigation.

While developing countries bear the brunt of disasters, ironically these are also the countries which have made fewer efforts to adapt their physical environments to mitigate the impact of such disasters and to insure themselves against disaster risks, partly because of the disincentive known as the "Samaritan's dilemma" (i.e. nations may underinvest in protective measures since they expect foreign donors to help when such disasters strike). ${ }^{28}$

\footnotetext{
${ }^{26}$ (a) There are numerous examples of government policies that prevented famines but also many others of policies that exacerbated shortages and caused famines and large-scale misery" The British, for example, believed in non-intervention in food markets during famines in India in the $19^{\text {th }}$ century. So food was exported while masses died of starvation. Other examples are worse, as they point to a causal role of government policies (e.g. food procurement policies that caused severe famines in Soviet Russia (i.e. the famine in Ukraine) in the 1930s and in Ethiopia in mid- 1980s). For an elaboration, see Dreze (1999).(b) As World Bank (2010) puts it, earthquakes, droughts and floods are natural hazards but the unnatural disasters are deaths and damages resulting from human acts of omission and commission.

27 In fact, 14 of the world's 19 mega cities (with 10 million or more inhabitants) are in coastal zones, and over 70 of the world's 100 largest cities can expect a strong earthquake at least once every 50 years (Freeman et al. 2003).

${ }^{28}$ For an elaboration of these concerns, see Freeman et al. (2003) and World Bank (2010).
} 
Within developing countries, the poor often bear the brunt of disasters for the following reasons: (i) they are located in areas that are more vulnerable to floods, hurricanes and earthquakes; (ii) disasters often disrupt food production, resulting in loss of livelihoods and higher food prices; (iii) finally, not only do the poor lose assets but they also lack access to risk- sharing mechanisms such as insurance. ${ }^{29}$ It is therefore not surprising that disasters substantially increase measured poverty (e.g. 50 per cent of the increase in the head-count ratio in the Philippines during the 1998 crisis was due to El Nino).

From a macro-economic perspective, the tax base shrinks while spending is greater. Trade balance may deteriorate, as exports decline and post-disaster reconstruction boosts demand for imports. Additionally, concurrent flight of foreign capital may put a downward pressure on the exchange rate and fuel inflation. Public sector debt ratios may worsen and domestic savings decline, forcing public and private sectors to borrow more from foreign sources ${ }^{30}$.

Catastrophic risks tend to be rare events but when they do occur there may be extreme outliers. These two factors imply that the occurrence and consequences of catastrophes are difficult to predict. Appropriate policy instruments for different catastrophes differ substantially in both objectives and modes of operation. Some policy instruments are designed to prevent catastrophes, others to reduce their likelihood, others to minimize their consequences, and still others to spread and thus mitigate the impact of their costs (Viscusi and Zeckhauser, 2010).

Catastrophes could be classified according to whether there are a few causal agents (BP Deepwater Horizon oil spill) or many (depletion of the ozone layer). If there are a few causal agents, it is easier to fix responsibility (Viscusi and Zeckhauser, 2011).

Prevention is often possible and cost-effective. Government expenditure on prevention is usually lower than on relief. While expenditure matters but also what it is spent on. Bangladesh, for example, reduced deaths from cyclones by spending modest sums on shelters, accurate weather forecasts, warnings and evacuation. These cost less than building large scale embankments (World Bank, 2010).

Risk mitigation through adaptation of physical environment includes land use planning (e.g. avoiding construction on seismic fault lines, vulnerable coastal regions, and ensuring that buildings are resistant to hurricanes and earthquakes); prevention of soil erosion; building of dams for flood control, and seawalls to break storm surges. Governments could also promote farming practices so that farmers can cope better with climatic variations - drought resistant crops - and adapt to longer-term changes.

While disaster insurance is extensive in many developed countries-in USA, for example, 50 per cent of direct catastrophic losses are insured-in developing countries (with per capita incomes $<\$ 10000$ per annum) insurance coverage is less than 10 per cent (and in countries with per capita incomes below $\$ 760$ the coverage is about 1 per cent). This lack of protection

${ }^{29}$ For an insightful exposition of the link between poverty and risks, see Dasgupta (2007).

${ }^{30}$ For a review of macro-economic impacts of natural disasters in selected Latin American countries- in particular, the process of recovery-see Mechler (2003) and Andersen (2005). For more recent evidence, see Noy, 2009). 
is further corroborated by the fact that Asia, which suffered half of all damages caused by natural disasters and two thirds of the casualties from them, accounted for 8 per cent of global purchase of catastrophic insurance while Japan, USA, and UK accounted for 55 per cent of the total (Freeman et al. 2003).

Adverse selection is a problem in disaster insurance but less than in other insurance markets, as many disasters can be predicted more accurately, as also the value of property at stake. In developing countries, however, specific problems arise from the thinness of insurance markets and ill-defined property rights (Freeman et al. 2003).

Two other problems are arguably more serious. One is the difficulty of risk spreading and the second is linked to the Samaritan's dilemma. While risk-spreading in developing countries in general should not be difficult- since the losses they face are a small fraction of global resources- it often is because of the segmented and shallow insurance markets. ${ }^{31}$ The Samaritan's dilemma, on the other hand, may arise from (i) households and firms underinvesting in insurance and undertaking adaptive measures on the presumption that governments would come to their rescue; (ii) governments may also underinvest in the hope that foreign donors would bail them out; and (iii) rich countries may find it difficult to scale down their ex post assistance in the absence of significant ex ante protective measures by governments in developing countries. The humanitarian urge to help when a disaster strikes is often overwhelmingly strong (Freeman et al. 2003).

New financial instruments (e.g. catastrophic bonds, swaps, and weather derivatives) have been devised to deal with disaster risk but with little impact. ${ }^{32}$

While there is potential for governments to correct market failures in the provision of disaster insurance, they are unable to act as insurers of last resort. Governments are often involved in compensating for losses that could be more efficiently handled by commercial insurance arrangements if the insurance market was sufficiently well developed. Distribution of claims among electoral constituencies creates moral hazard issues and bureaucratic corruption (Andersen, 2005). ${ }^{33}$

Governments could help correct insurance market failures through (i) tax deductions, (ii) subsidies, (iii) guarantees to insurers and reinsurers, (iv) hedging of such guarantees on world's reinsurance and capital markets, and (v) mandatory levels of insurance. ${ }^{34}$ A general

${ }^{31}$ In the 1990s, the Caribbean countries, for example, faced insurance rate increases of between 200-300 per cent, due to indemnity payments for large hurricane and earthquake losses worldwide (Freeman et al. 2003).

${ }^{32}$ Froot (2001) makes an important observation that catastrophic bonds cause a reduction in the barriers to entry into reinsurance. Indeed, it is the barriers to entry and not the amount of capacity in current use that explains deviations from fair pricing.

${ }^{33}$ For insightful treatments of the market for catastrophic risks, see Kunreuther (1997), Froot (2001) and Froot and O’Connell (1997), among others.

${ }^{34}$ Lave and Apt (2006) emphasise government's important role in providing information to people regarding the risks they face, as they do not have well-formulated risk-beliefs concerning low probability but high loss natural catastrophes. Government information provision could remedy this inadequacy and foster more rational risk taking. There is one important caveat, however. Even when there is substantial scientific basis for making risk judgments, as with hurricane warning systems, the risk is not known until the emergency has passed (Viscusi and Zeckhauser, 2011). 
response to the Samaritan's dilemma is to require those at risk to undertake ex ante measures to reduce the harm that they will suffer if the hazard occurs. ${ }^{35}$ Donors, for example, may credibly commit emergency assistance to countries deemed to have taken disaster mitigation measures (e.g. provision for self-insurance, sea wall protection, enforcement of building guidelines in coastal and other hazard prone- areas). This would help in overcoming a basic inefficiency in disaster insurance and free resources for other development purposes (Freeman et al. 2003). ${ }^{36}$

Some observations to address donor concerns and a more coordinated disaster prevention and mitigation strategy are made below.

A major strategic concern is mainstreaming of disaster prevention and mitigation among multilateral development agencies and governments. This rests on the presumption that the response to disasters has been reactive and tactical, and not strategic in the sense that the emergencies caused by natural hazards (e.g. floods, earthquakes) are not periodic but ongoing in the context of highly vulnerable countries (World Bank, 2006, 2010). Pacific-rim states, for example, will continue to be hit by earthquakes and floods, while low-lying coastal areas on the Bay of Bengal will continue to get flooded.

Recovery from a disaster and poverty reduction go hand in hand. Choices made during the initial phase could influence the outcomes in terms of poverty favourably or unfavourably over time. If interventions do not go beyond short-term relief and shy away from rebuilding of livelihoods and reconstruction from a longer-term perspective, communities/regions highly vulnerable to natural hazards (e.g. low lying coastal areas are highly vulnerable to floods) are likely to fare worse with recurrent catastrophes.

Why should multilaterals/ developing countries be concerned? As noted earlier, a striking piece of evidence is that the damage from the Kashmir earthquake of December, 2005, exceeded total development assistance in the preceding three years (World Bank, 2006). A related question is why the longer-term implications of building resilience against such disasters do not get the priority they deserve. Typically, disaster responses are like a military operation with a heavy reliance on command and control systems designed to make a chaotic situation manageable (World Bank, 2006). In such a process, people and institutions that

35 Mitigation also encourages reinsurers to reduce their rates: encouraging policy holders to adopt riskmitigation measures provides an additional option for small insurers to meet insolvency constraints and puts pressure on reinsurers not too charge too high a premium (Kunreuther, 1997). For a sample of studies of why reinsurance is expensive, see Froot (2001) and Froot and O’Connell (1997).

${ }^{36}$ In this context, the findings from a US survey are illuminating: (i) over 90 per cent of the respondents believed that they faced average or below average fatality risks from natural disasters; (ii) experiencing a hurricane or a tornado decreases the percentage of who rate their risks below average by about 10 per cent, but a similar experience with floods and earthquakes has a minimal effect on the victims' perceptions. For each risk, having experience with it shifts perceived risks upwards. However, this updating (anchoring) is insufficient. (iii) Over 82 per cent of the respondents favoured subsidized insurance and relief for disaster victims; the percentage favouring these measures for the victims who chose to live in disaster prone-areas was, however, much smaller (about 37 per cent). This is referred to as "efficient compassion. Individuals who perceive themselves to be at greater personal risk are more supportive of government assistance. So there are elements of both compassion and self-interest in support of government assistance (Viscusi and Zeckhauser, 2006). From a larger perspective of the developing countries, see World Bank (2010). 
might help rebuild affected communities are left out. ${ }^{37}$ What makes matters worse is that little attention is paid to how the next disaster could be averted. Neither donor funding is geared to that goal nor developing countries, as soon after the emergency is over other development priorities take over. So the key interrelationships between recovery, disaster prevention and an abrupt worsening of poverty reduction over a period of time must be addressed in a coherent strategy through development assistance. Even small, incremental efforts can go a long way towards disaster prevention (IFRC, 2001).

Need for building of ownership through borrower financing and involvement of local communities, preservation of social networks in rehabilitation programmes, support for complementary activities (e.g. rehabilitation centres must ensure provision of safe water and sanitation), and maintenance of infrastructure ${ }^{38}$.

Evidence has accumulated pointing to coordination failure turning natural catastrophes into disasters. Marris (2005), for example, documents that much of the destruction and deaths in the wake of the 2004 tsunami could have been averted. In fact, there was a chain of coordination failures $^{39}$. Another case in point is the Orissa cyclone of 1999. But a cyclone three years later (in 2002) resulted in far fewer deaths as both official agencies and affected communities responded more quickly and in a coordinated manner (Thomalla and Schmuck, 2004). The mortalities in the wake of the Kashmir earthquake in 2005 were staggering for a variety of reasons, including slow and uncoordinated response, inaccessible terrain, tightfistedness of donors, mistrust between neighbours and failure to enforce building codes (The Economist, 15 October, 2005).

Donors typically respond to disasters after they strike: about a fifth of total humanitarian aid between 2000-2008 was spent on disaster relief. Donors concerned with prevention could earmark official development aid (rather than humanitarian aid) to prevention- related activities. And such aid, used effectively, could reduce issues arising from the Samaritan's dilemma (World Bank, 2010). .

\footnotetext{
${ }^{37}$ A best practice example of how vulnerability to flooding could be reduced by preventing environmental degradation comes from a highly eroded region of China. Small check dams, planting of trees, bushes, and shrubs on sloping lands, and building of terraces, using contour ditches and stone barriers, helped eliminate flash floods, and sediment inflows to the Yellow river. In due course, incomes of poor farmers rose. The design of this project and its implementation were in consultation with various stakeholders-especially local communities. Much of its success also depended on the initial results demonstrating the potential of improved practices in reducing poverty (World Bank, 2006).

${ }^{38}$ It is crucial to avoid unnecessary processes and the establishment of new bureaucracies, and build instead on existing public, private and local self-help organisations. Capacity-building may include support for public and private sector providers of services to rural communities, but the major thrust must be on community organizations.

39 Prediction of a tsunami with any useful time advantage requires data on small changes in sea level and pressure collected directly from the floor and surface of the sea. Instruments that could provide such data are already in the Indian Ocean. However, a coordinated and continuous monitoring is needed, under the auspices of UNESCO's Intergovernmental Oceanographic Commission (IOC). But collection of information and its dissemination are often difficult. Data exchange, hazard analysis, and hazard mapping thus become difficult. Sharing of data is often resisted for security, commercial and defence reasons (World Bank, 2010)..
} 


\section{Concluding Observations}

Let us first summarise the main findings, followed by observations from a broad policy perspective.

Our analysis has drawn attention to the higher frequency of natural disasters and deaths associated with them. There are regional variations as well as across countries ranked by income levels. A somewhat surprising finding is that, while the frequency of disasters was not the highest in Low Income countries, they were far deadlier relative to higher income countries. But as these are essentially averages, they cannot be interpreted as trends.

Floods were the most frequent disaster, accounting for well over one-third of the total disasters during 1985-1994. The next most frequent were windstorms that accounted for a quarter of the disasters. Most disasters became more frequent in the next decade (19952004). While the share of floods rose, that of windstorms declined. Both droughts and famine also became more frequent but the share of the former rose and that of the latter - already low - declined.

Windstorms accounted for a little under one-half of the deaths in 1985-94, followed by earthquakes accounting for over a quarter of the deaths. The next decade, however, witnessed wave surges claiming one-third of the deaths, followed closely by famines that claimed about the same share. While famines and wave surges became far deadlier (per disaster) during 1995-2004, floods became the deadliest (per million of population). So, while the aggregate of disasters became deadlier on various criteria, deadliness of some disasters varied with the criterion used.

A selection of the regression results on occurrence of disasters was given. Much of this analysis, however, was robust to changes in specification and in sample periods. In particular, countries that were prone to natural disasters in 1970-79 continued to be so in the next decade or two. Geophysical factors (e.g. land area, whether land locked, elevation and distance from a coast) had an important role in explaining inter-country variation in the occurrence of natural disasters. Somewhat surprisingly, the effect of level of development was weak or non-existent.

Income (and by implication its growth) matter a great deal in averting disaster-related deaths. While learning from past experience takes diverse forms and magnitudes, our assessment suggests that it has been far from adequate. (Lagged) disasters are associated with higher frequency of disasters which in turn cause higher fatalities. Also, the direct effect of lagged deaths on subsequent deaths is high, further pointing to limited learning from past experience of severe disasters. While institutions matter, our analysis was not detailed enough to validate their role. 
Even moderate learning can save a large number of deaths (e.g. through early warning systems, better coordination between governments and communities likely to be affected). Growth acceleration would also help avert deaths through more resources for disaster prevention and mitigation capabilities. A combination of the two-learning from past experience and more resources for disaster prevention and mitigation-would of course result in a massive reduction in deaths from disasters.

Attention is drawn to segmented and shallow disaster insurance markets and governments' role in developing them; the Samaritan's dilemma in providing emergency assistance to poor countries that neglect investment in protective measures; need for mainstreaming of disaster prevention and mitigation among multilateral development agencies and governments, and the imperative of better coordination among them; why short-term relief must be combined with rebuilding of livelihoods and reconstruction, and the potential for public-private partnerships; and, above all, the need for building ownership of local communities and preservation of social networks.

In conclusion, while our evidence points to growing vulnerability to natural disasters and their grave implications for human security, a challenge for governments and development assistance is to combine growth acceleration with speedy relief and durable reduction in vulnerability. If our analysis has any validity, there are indeed grounds for optimism. 
Annex 1

Table A.1.1

Definitions of Natural Hazards

\begin{tabular}{|c|c|c|}
\hline Type & Hazard & Definition \\
\hline \multirow[t]{4}{*}{ (a) Hydro-Meteorological } & $\begin{array}{l}\text { (i) Hurricanes and } \\
\text { Tropical Storms }\end{array}$ & $\begin{array}{l}\text { Large-scale, closed circulation system in the } \\
\text { atmosphere with low barometric pressure and } \\
\text { clockwise in the southern hemisphere }\end{array}$ \\
\hline & (ii) Floods & $\begin{array}{l}\text { Temporary inundation of normally dry land by } \\
\text { overflowing lakes or rivers, precipitation, storm } \\
\text { surges, tsunami, waves, mudflow, and lahar. } \\
\text { Also caused by the failure of water retaining } \\
\text { structures, ground water seepage and water } \\
\text { back-up in sewer system. }\end{array}$ \\
\hline & (iii) Drought & $\begin{array}{l}\text { Lack or insufficiency of rain for an extended } \\
\text { period that causes hydrological imbalance and, } \\
\text { consequently, water shortage, crop damage, } \\
\text { stream flow reduction and depletion of } \\
\text { groundwater and soil moisture. It occurs when, } \\
\text { for a considerable period, evaporation and } \\
\text { transpiration (the release of underground water } \\
\text { into the atmosphere through vegetation) exceeds } \\
\text { precipitation. }\end{array}$ \\
\hline & (iv) Forest Fires & $\begin{array}{l}\text { Uncontrolled fires whose flames can consume } \\
\text { trees and other vegetation of more than } 6 \text { feet } \\
(1.8 \mathrm{~m}) \text { in height. These often reach the } \\
\text { proportions of a major conflagaration and are } \\
\text { sometimes begun by combustion and heat from } \\
\text { surface and ground fires. }\end{array}$ \\
\hline \multirow[t]{5}{*}{ (b) Geophysical } & (i) Earthquake & $\begin{array}{l}\text { Sudden tremor of the earth's strata caused by } \\
\text { movements of tectonic plates along fault lines in } \\
\text { mountain ranges or mid oceanic ranges }\end{array}$ \\
\hline & (ii) Tsunami & $\begin{array}{l}\text { Wave train or series of waves generated in } \\
\text { water by an impulsive disturbance (such as } \\
\text { earthquakes) that vertically displace gigantic } \\
\text { water columns. Tsunamis may reach a maximum } \\
\text { run-up or above- sea-level height of } 10,20 \text {, or } \\
\text { even } 30 \text { metres. }\end{array}$ \\
\hline & (iii) Slides & $\begin{array}{l}\text { Downward slope movement of soil, rock, mud } \\
\text { or snow because of gravity. A common source } \\
\text { of slides is prolonged torrential downpours of } \\
\text { rain or the accumulation of heavy snow. Mass } \\
\text { displacement of large mud, snow or rocks can } \\
\text { also be triggered by seismic waves. }\end{array}$ \\
\hline & (iv) Lahars & $\begin{array}{l}\text { Mudflows that are caused by the melting of the } \\
\text { ice cap by lava from a volcano or the downhill } \\
\text { run-off of volcanic ash because of heavy rainfall. }\end{array}$ \\
\hline & (v) Volcanic Eruption & $\begin{array}{l}\text { Process whereby molten lava, fragmented rocks } \\
\text { or gases are released to the earth’s surface } \\
\text { through a deep crater, vent or fissure }\end{array}$ \\
\hline
\end{tabular}

Source: Adapted from Auffret (2003). 
Table A.1.2

\section{Classification by Income}

For operational and analytical purposes, the World Bank's main criterion for classifying economies is gross national income (GNI) per capita. Based on its GNI per capita, every economy is classified as low income, middle income (subdivided into lower middle and upper middle), or high income. Other analytical groups, based on geographic regions and levels of external debt, are also used.

\section{Definitions of groups}

Geographic region: Classifications and data reported for geographic regions are for low-income and middleincome economies only. Low-income and middle-income economies are sometimes referred to as developing economies. Classification by income does not necessarily reflect development status.

Income group: Economies are divided according to 2004 GNI per capita, calculated using the World Bank Atlas method. The groups are: low income, $\$ 825$ or less; lower middle income, $\$ 826$ - \$3,255; upper middle income, $\$ 3,256$ - \$10,065; and high income, $\$ 10,066$ or more.

Source: Adapted from World Development Indicators (WDI, 2006). 


\section{Hydro-Meteorological and Geophysical Disasters}

Here a disaggregated analysis of natural disasters into hydro-meteorological and geophysical disasters is carried out. The empirical evidence confirms that both their frequencies and impacts differ.

Table A.2.1

Different Types of Natural Disasters and Their Death Tolls

\begin{tabular}{|c|c|c|c|c|c|c|c|c|c|c|}
\hline \multirow{3}{*}{ Disaster Type } & Frequency & Frequency & Deaths & Deaths & $\begin{array}{c}\text { Deaths } \\
\text { per } \\
\text { Million }\end{array}$ & $\begin{array}{l}\text { Deaths } \\
\text { per } \\
\text { Million }\end{array}$ & $\begin{array}{c}\text { Deaths } \\
\text { per } \\
\text { Disaster }\end{array}$ & $\begin{array}{c}\text { Deaths } \\
\text { per } \\
\text { Disaster }\end{array}$ & $\begin{array}{l}\text { Disasters } \\
\text { per } \\
\text { million }\end{array}$ & $\begin{array}{l}\text { Disasters } \\
\text { per } \\
\text { million }\end{array}$ \\
\hline & $1985-94$ & $1995-04$ & $1985-94$ & 1995-04 & $1985-94$ & $1995-04$ & $1985-94$ & 1995-04 & $1985-94$ & 1995-04 \\
\hline & $(\%)$ & $(\%)$ & $(\%)$ & $(\%)$ & & & & & & \\
\hline Hydro-meteorological & $\begin{array}{c}1111 \\
(75.94)\end{array}$ & $\begin{array}{c}1823 \\
(80.38)\end{array}$ & $\begin{array}{l}248602 \\
(64.60)\end{array}$ & $\begin{array}{l}615792 \\
(88.77)\end{array}$ & 60 & 128 & 224 & 338 & 0.27 & 0.38 \\
\hline Geophysical & $\begin{array}{c}352 \\
(24.06)\end{array}$ & $\begin{array}{c}445 \\
(19.62)\end{array}$ & $\begin{array}{l}136244 \\
(35.40)\end{array}$ & $\begin{array}{c}77897 \\
(11.23)\end{array}$ & 33 & 16 & 387 & 175 & 0.08 & 0.09 \\
\hline Total & $\begin{array}{c}1463 \\
(100.00)\end{array}$ & $\begin{array}{c}2268 \\
(100.00)\end{array}$ & $\begin{array}{c}384846 \\
(100.00)\end{array}$ & $\begin{array}{c}693689 \\
(100.00)\end{array}$ & 92 & 144 & 263 & 306 & 0.35 & 0.47 \\
\hline
\end{tabular}

1. Based on the classification in Auffret (2003). Calculations based on EM-DAT. Note that rich OECD and non-OECD countries are excluded. 
- As may be noted from Table A.2.1, the frequencies of both hydro-meteorological and geophysical disasters were considerably higher in 1995-04, relative to 1985-94. If these frequencies are expressed as a ratio of population, there was an increase in the frequency of the former while that of the latter remained unchanged.

- However, a vast majority of the disasters were hydro-meteorological during 1985-94, and their share rose during the next decade.

- So also was the case with their share of deaths-this rose from about 65 per cent during 198594 to about 88 per cent in 1995-04, while there was a sharp reduction in that of geophysical disasters.

- Hydro-meteorological disasters became deadlier during 1995-04 on the criterion of deaths per disaster while geophysical ones recorded a decline in their deadliness.

- A similar pattern is revealed by our preferred criterion of deaths per million of population, confirming a more than doubling of the deadliness of hydro-meteorological ones and a halving of that of geophysical.

In sum, while both types of disasters became more frequent, only hydro-meteorological disasters became far deadlier.

Let us now turn to their frequencies and measures of their deadliness by region.

- East Asia and the Pacific accounted for just under one-third of hydro-meteorological disasters, followed by Latin America and the Caribbean, South Asia, and Sub-Saharan Africa during 1985-94. The (relative) frequencies changed during 1995-04. While both East Asia and the Pacific, and South Asia recorded moderate reductions, Europe and Central Asia, and Sub-Saharan Africa, among others, recorded higher shares.

- Hydro-meteorological disasters per million of population were, however, most frequent in Latin America and the Caribbean, followed closely by Sub-Saharan Africa in 1985-94. Both also recorded higher frequencies in 1995-04.

- Over 90 per cent of the deaths were concentrated in South Asia, and East Asia and the Pacific during 1985-94, with the majority in the former. The shares of the remaining regions were relatively small.

Going by the criterion of deaths per disaster, hydro-meteorological ones were the deadliest in South Asia, followed by East Asia and the Pacific, and Sub-Saharan Africa. There was a sharp reversal in the next decade, with these disasters becoming the deadliest in East Asia and the Pacific, followed by South Asia. Also, while Sub-Saharan Africa experienced more deadly disasters, Latin America and the Caribbean experienced a reduction. 
Table A.2.2

Hydro-Meteorological Disasters and Their Death Toll

\begin{tabular}{|c|c|c|c|c|c|c|c|c|c|c|}
\hline Region & $\begin{array}{l}\text { Number } \\
\text { of } \\
\text { Disasters } \\
(85-94)\end{array}$ & $\begin{array}{l}\text { Number } \\
\text { of } \\
\text { Disasters } \\
(95-04)\end{array}$ & $\begin{array}{l}\text { Deaths } \\
(85-94)\end{array}$ & $\begin{array}{l}\text { Deaths } \\
(95-04)\end{array}$ & $\begin{array}{l}\text { Deaths } \\
\text { per } \\
\text { million } \\
(85-94)\end{array}$ & $\begin{array}{l}\text { Deaths } \\
\text { per } \\
\text { million } \\
(95-04)\end{array}$ & $\begin{array}{l}\text { Deaths } \\
\text { per } \\
\text { disaster } \\
(85-94)\end{array}$ & $\begin{array}{l}\text { Deaths } \\
\text { per } \\
\text { disaster } \\
(95-04)\end{array}$ & $\begin{array}{l}\text { Disasters } \\
\text { per } \\
\text { million } \\
(85-94)\end{array}$ & $\begin{array}{c}\text { Disasters } \\
\text { per } \\
\text { million } \\
(95-04)\end{array}$ \\
\hline Latin America \& Caribbean & $\begin{array}{c}232 \\
(20.88) \\
\end{array}$ & $\begin{array}{c}394 \\
(21.61) \\
\end{array}$ & $\begin{array}{c}6902 \\
(2.78) \\
\end{array}$ & $\begin{array}{c}62105 \\
(10.09) \\
\end{array}$ & 16 & 126 & 30 & 158 & 0.55 & 0.8 \\
\hline South Asia & $\begin{array}{c}207 \\
(18.63) \\
\end{array}$ & $\begin{array}{c}268 \\
(14.70) \\
\end{array}$ & $\begin{array}{l}185847 \\
(74.76)\end{array}$ & $\begin{array}{l}101339 \\
(16.46) \\
\end{array}$ & 168 & 78 & 898 & 378 & 0.19 & 0.21 \\
\hline East Asia \& Pacific & $\begin{array}{c}353 \\
(31.77) \\
\end{array}$ & $\begin{array}{c}489 \\
(26.82) \\
\end{array}$ & $\begin{array}{c}38437 \\
(15.46) \\
\end{array}$ & $\begin{array}{l}432093 \\
(70.17) \\
\end{array}$ & 24 & 242 & 109 & 884 & 0.22 & 0.27 \\
\hline Europe \& Central Asia & $\begin{array}{c}62 \\
(5.58) \\
\end{array}$ & $\begin{array}{c}213 \\
(11.68)\end{array}$ & $\begin{array}{c}2327 \\
(0.94)\end{array}$ & $\begin{array}{c}4076 \\
(0.66) \\
\end{array}$ & 6 & 10 & 38 & 19 & 0.15 & 0.51 \\
\hline Middle East \& North Africa & $\begin{array}{c}62 \\
(5.58) \\
\end{array}$ & $\begin{array}{c}110 \\
(6.03) \\
\end{array}$ & $\begin{array}{c}2926 \\
(1.18) \\
\end{array}$ & $\begin{array}{r}3768 \\
(0.61) \\
\end{array}$ & 14 & 14 & 47 & 34 & 0.29 & 0.42 \\
\hline Sub-Saharan Africa & $\begin{array}{c}195 \\
(17.55) \\
\end{array}$ & $\begin{array}{c}349 \\
(19.14) \\
\end{array}$ & $\begin{array}{l}12163 \\
(4.89) \\
\end{array}$ & $\begin{array}{l}12411 \\
(2.02) \\
\end{array}$ & 28 & 23 & 62 & 36 & 0.45 & 0.63 \\
\hline Total & $\begin{array}{c}1111 \\
(100.00) \\
\end{array}$ & $\begin{array}{c}1823 \\
(100.00)\end{array}$ & $\begin{array}{c}248602 \\
(100.00) \\
\end{array}$ & $\begin{array}{c}615792 \\
(100.00) \\
\end{array}$ & 60 & 128 & 224 & 338 & 0.27 & 0.38 \\
\hline
\end{tabular}

Calculations based on EM-DAT. Note that rich OECD and non-OECD countries are excluded. 
- This pattern is largely reproduced when deaths are expressed as a ratio of the population. These disasters were the deadliest in South Asia during 1985-94, followed by Sub-Saharan Africa, and East Asia and the Pacific. However, but consistent with the previous normalization, deadliness of these disasters shot up in East Asia and the Pacific (by a multiple of 10) and in Latin America and the Caribbean (by a multiple of 8) in the next decade. While there was a reduction in the deadliness of these disasters in South Asia, the fatalities were markedly higher than in all other regions (excluding the previous two).

Let us now turn to geophysical disasters by region.

- They were the most frequent in East Asia and the Pacific, followed by Latin America and the Caribbean during 1985-94.

- While the share of East Asia and the Pacific rose more than moderately, that of Latin America and the Caribbean fell slightly. South Asia recorded a slight increase during the next decade.

- When these are normalized by population, Latin America and the Caribbean recorded the highest frequency, followed by Middle East and North Africa, and Europe and Central Asia during 1985-94.

- The distribution of deaths is strikingly different from that of hydro-meteorological ones. Latin America and the Caribbean, Middle East and North Africa, and Europe and Central Asia accounted for over 80 per cent of the deaths, with the two sub-regions of Asia accounting for less than one-fifth of the share during 1985-94.

- During the next decade significant reversals occurred. While geophysical disasters in Middle East and North Africa accounted for over 42 per cent of the deaths, the share of South Asia rose by a multiple of 4 . The combined share of these two regions was about 83 per cent. There were sharp reductions in the shares of Latin America and the Caribbean, and Europe and Central Asia.

- Deaths per disaster were highest in Middle East and North Africa, followed by Europe and Central Asia, and Latin America and the Caribbean during 1985-94.

- While these disasters remained the deadliest in Middle East and North Africa but with lower fatalities, there was a marked spurt in South Asia, and substantial reductions in Latin America and the Caribbean, and Sub-Saharan Africa during the next decade.

- With deaths normalized by population, there are a few changes. While these disasters were the deadliest in Middle East and North Africa, the next in rank was Latin America and the Caribbean, followed by Europe and Central Asia. While Middle East and North Africa remained the deadliest with a marked reduction in fatalities, the only region that witnessed higher fatalities was South Asia.

An alternative classification of these types of natural disasters by level of income is revealing. 
Table A.2.3

Geophysical Disasters and Their Death Toll

\begin{tabular}{|c|c|c|c|c|c|c|c|c|c|c|}
\hline Region & $\begin{array}{c}\text { Number } \\
\text { of } \\
\text { Disasters } \\
(85-94)\end{array}$ & $\begin{array}{c}\text { Number } \\
\text { of } \\
\text { Disasters } \\
(95-04)\end{array}$ & $\begin{array}{l}\text { Deaths } \\
\text { (85-94) }\end{array}$ & $\begin{array}{l}\text { Deaths } \\
(95-04)\end{array}$ & $\begin{array}{l}\text { Deaths } \\
\text { per } \\
\text { million } \\
(85-94)\end{array}$ & $\begin{array}{l}\text { Deaths } \\
\text { per } \\
\text { million } \\
(95-04)\end{array}$ & $\begin{array}{c}\text { Deaths } \\
\text { per } \\
\text { disaster } \\
(85-94)\end{array}$ & $\begin{array}{c}\text { Deaths } \\
\text { per } \\
\text { disaster } \\
(95-04)\end{array}$ & $\begin{array}{l}\text { Disasters } \\
\text { per } \\
\text { million } \\
(85-94)\end{array}$ & $\begin{array}{l}\text { Disasters } \\
\text { per } \\
\text { million } \\
(95-04)\end{array}$ \\
\hline & $\%$ & $\%$ & $\%$ & $\%$ & & & & & & \\
\hline Latin America \& Caribbean & $\begin{array}{c}94 \\
(26.70)\end{array}$ & $\begin{array}{c}105 \\
(23.60)\end{array}$ & $\begin{array}{c}41114 \\
(30.18)\end{array}$ & $\begin{array}{c}4721 \\
(6.06)\end{array}$ & 97 & 10 & 437 & 45 & 0.22 & 0.21 \\
\hline South Asia & $\begin{array}{c}42 \\
(11.93)\end{array}$ & $\begin{array}{c}59 \\
(13.26) \\
\end{array}$ & $\begin{array}{c}14510 \\
(10.65)\end{array}$ & $\begin{array}{c}31499 \\
(40.44)\end{array}$ & 13 & 24 & 345 & 534 & 0.04 & 0.05 \\
\hline East Asia \& Pacific & $\begin{array}{c}112 \\
(31.82)\end{array}$ & $\begin{array}{c}170 \\
(38.20) \\
\end{array}$ & $\begin{array}{c}9773 \\
(7.17) \\
\end{array}$ & $\begin{array}{c}4424 \\
(5.68)\end{array}$ & 6 & 2 & 87 & 26 & 0.07 & 0.1 \\
\hline Europe \& Central Asia & $\begin{array}{c}54 \\
(15.34) \\
\end{array}$ & $\begin{array}{c}57 \\
(12.81) \\
\end{array}$ & $\begin{array}{c}27904 \\
(20.48) \\
\end{array}$ & $\begin{array}{c}3728 \\
(4.79) \\
\end{array}$ & 69 & 9 & 517 & 65 & 0.13 & 0.14 \\
\hline Middle East \& North Africa & $\begin{array}{c}33 \\
(9.38)\end{array}$ & $\begin{array}{c}35 \\
(7.87)\end{array}$ & $\begin{array}{c}41076 \\
(30.15)\end{array}$ & $\begin{array}{c}33021 \\
(42.39)\end{array}$ & 192 & 126 & 1245 & 943 & 0.15 & 0.13 \\
\hline Sub-Saharan Africa & $\begin{array}{c}17 \\
(4.83) \\
\end{array}$ & $\begin{array}{c}19 \\
(4.27) \\
\end{array}$ & $\begin{array}{c}1867 \\
(1.37) \\
\end{array}$ & $\begin{array}{c}504 \\
(0.65) \\
\end{array}$ & 4 & 1 & 110 & 27 & 0.04 & 0.03 \\
\hline Total & $\begin{array}{c}352 \\
(100.00)\end{array}$ & $\begin{array}{c}445 \\
(100.00)\end{array}$ & $\begin{array}{c}136244 \\
(100.00)\end{array}$ & $\begin{array}{c}77897 \\
(100.00)\end{array}$ & 33 & 16 & 387 & 175 & 0.08 & 0.09 \\
\hline
\end{tabular}

Calculations based on EM-DAT. Note that rich OECD and non-OECD countries are excluded. 
Table A.2.4

Hydro-Meteorological Disasters and Their Death Tolls by Income

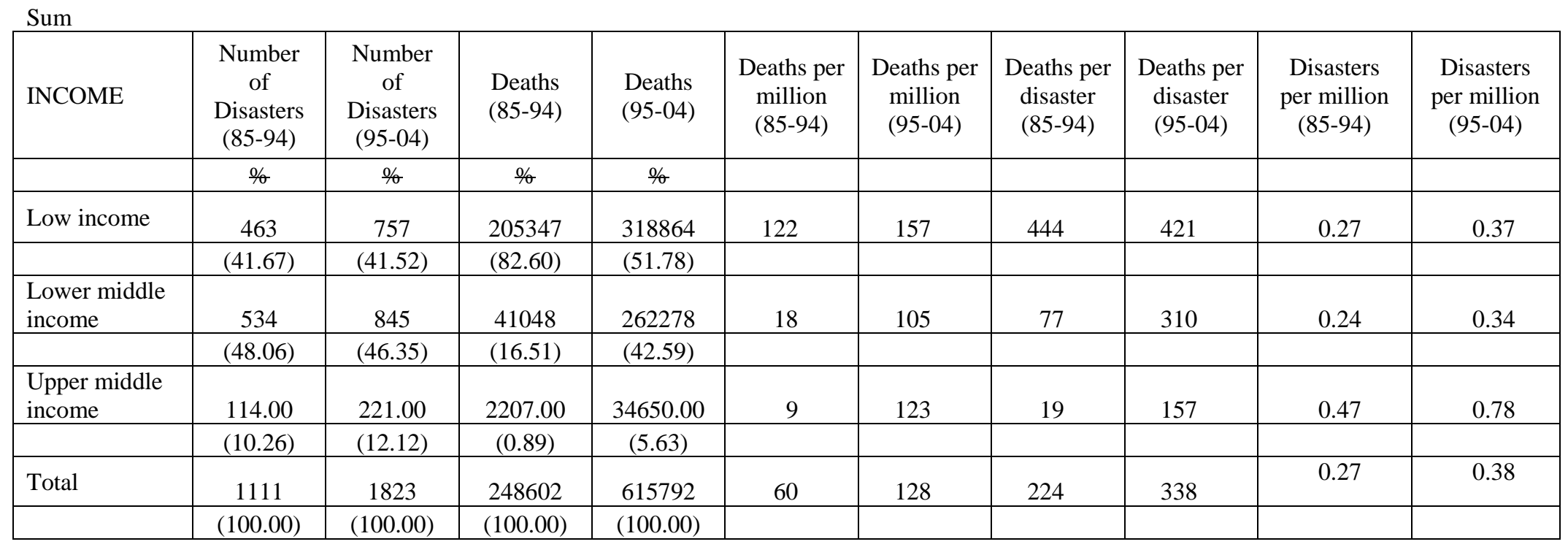

Calculations based on EM-DAT. Note that rich OECD and non-OECD countries are excluded. 
Table A.2.5

Geophysical Disasters and Their Death Tolls by Income

\begin{tabular}{|c|c|c|c|c|c|c|c|c|c|c|}
\hline INCOME & $\begin{array}{c}\text { Number } \\
\text { of } \\
\text { Disasters } \\
(85-94)\end{array}$ & $\begin{array}{l}\text { Number } \\
\text { of } \\
\text { Disasters } \\
(95-04)\end{array}$ & $\begin{array}{l}\text { Deaths } \\
\text { (85-94) }\end{array}$ & $\begin{array}{l}\text { Deaths } \\
(95-04)\end{array}$ & $\begin{array}{l}\text { Deaths per } \\
\text { million } \\
(85-94)\end{array}$ & $\begin{array}{c}\text { Deaths per } \\
\text { million } \\
(95-04)\end{array}$ & $\begin{array}{c}\text { Deaths per } \\
\text { disaster } \\
(85-94)\end{array}$ & $\begin{array}{l}\text { Deaths per } \\
\text { disaster } \\
(95-04)\end{array}$ & $\begin{array}{l}\text { Disasters } \\
\text { per } \\
\text { million } \\
(85-94)\end{array}$ & $\begin{array}{l}\text { Disasters } \\
\text { per } \\
\text { million } \\
(95-04)\end{array}$ \\
\hline & $\%$ & $\%$ & $\%$ & $\%$ & & & & & & \\
\hline Low income & 81 & 114 & 17516 & 32350 & 10 & 16 & 216 & 284 & 0.05 & 0.06 \\
\hline & (23.01) & $(25.62)$ & (12.86) & (41.53) & & & & & & \\
\hline $\begin{array}{l}\text { Lower middle } \\
\text { income }\end{array}$ & 240 & 296 & 108591 & 45161 & 49 & 18 & 452 & 153 & 0.11 & 0.12 \\
\hline & (68.18) & $(66.52)$ & $(79.70)$ & (57.98) & & & & & & \\
\hline $\begin{array}{l}\text { Upper middle } \\
\text { income }\end{array}$ & 31 & 35 & 10137 & 386 & 41 & 1 & 327 & 11 & 0.13 & 0.12 \\
\hline
\end{tabular}

Calculations based on EM-DAT. Note that rich OECD and non-OECD countries are excluded. 
- Low income and Lower Middle Income countries accounted for the vast majority of hydrometeorological disasters (about 90 per cent) during 1985-94. There was a slight reduction in their share over the next decade.

- While each income group recorded higher frequencies per million of population, the largest increase occurred in Upper Middle Income countries.

- Deaths, however, were more concentrated, with Low Income and Lower Middle Income countries accounting for nearly all fatalities during 1985-94. During the next decade, their combined share declined. While that of Low Income countries dropped sharply from about 83 per cent to about 52 per cent, that of Lower Middle Income countries climbed from about 17 per cent to about 43 per cent.

- Deaths per disaster were the highest in Low Income countries, followed by Lower Middle Income countries but with considerably fewer fatalities in 1985-94. While the deadliness of hydro-meteorological disasters remained highest in South Asia but with fewer fatalities, it shot up in Lower Middle Income countries as well as in Upper Middle Income countries.

- Deaths per million reveal a different pattern across these income groups. They were highest in Low Income countries during 1985-94 and remained so during the next decade with higher fatalities. The fatalities shot up in the remaining two groups as well-especially among Upper Middle Income countries.

The frequencies and deadliness of hydro-meteorological and geophysical disasters differ across these income groups as well.

- The majority of geophysical disasters occurred in Low Income and Lower Middle Income groups, with the latter accounting for more than two-thirds. The (relative) frequencies changed little during the next decade, with a slightly higher share of Low Income countries.

- Frequencies of such disasters per million of population were highest in Lower Middle Income countries and remained so in the next decade with a slight increase.

- Deaths, however, were mostly concentrated in the two lowest income groups, accounting for nearly 93 per cent of the total during 1985-94. The bulk of the deaths occurred in Lower Middle Income countries. While this group recorded a sharp reduction during 1995-04, the share of Low Income countries shot up.

- Deaths per disaster were highest in Lower Middle Income countries during 1985-94 but they experienced a marked reduction in fatalities in the next decade. Upper Middle income countries also recorded a substantial reduction. By contrast, the fatalities rose in Low Income countries, surpassing those in other income groups.

- A slightly different pattern of deadliness is revealed by deaths per million. Geophysical disasters were the deadliest in Lower Middle Income countries, followed closely by Upper Middle Income countries during 1985-94. While the deadliness declined in both Lower Middle Income and Upper Middle Income groups-especially the latter-there was a more than moderate rise in Low Income countries.

To sum up, both the frequency and deadliness of hydro-meteorological and geophysical disasters differ over time, across regions and income groups. The main findings are that a vast majority of natural disasters were hydro-meteorological and their (relative) frequency rose during more recent years; not only was the deadliness of the former greater in the aggregate sample it also doubled while that of the latter halved during more recent years; and, while hydro-meteorological disasters also became deadlier in both Low Income and Lower Middle Income groups- especially in the lattergeophysical ones did so only in the former. 


\section{Reliability of Data on Natural Disasters}

Annex 3

As discussed earlier, doubts have been raised about the reliability of numbers of natural disasters and deaths associated with them. A careful scrutiny of EM-DAT and its cross-validation from other independent sources confirm that (i) in general, the quality of the data since the 1970s has been uniformly good; and (ii) the mortality estimates are more reliable than those of people affected and economic losses.

While some doubts will persist, we report below the results of two regressions and corresponding graphs that confirm that neither the frequency of natural disasters nor the deaths associated with them vary systematically with exposure to mass media- in particular, availability of newspapers per 1000 people during 1997-2000.

In Table A. 3 1, we regress the residuals from our preferred specification for occurrence of natural disasters during 1980-2004 on newspaper circulation. As may be noted from the results, the coefficient of newspaper circulation is not significant, implying the absence of a relationship between the two variables.

Table A.3.1

Residuals of Disasters and Exposure to Newspapers

\begin{tabular}{|l|rrl|}
\hline \multicolumn{4}{|c|}{ No. of observations $=55$} \\
\hline \multicolumn{3}{|c|}{$\mathrm{F}(1,53)=0.60$} \\
\hline \multicolumn{3}{|c|}{ Prob. $>\mathrm{F}=0.4419$} \\
\hline Residual natural disasters during 1980-2004 & \multicolumn{3}{c|}{ Coefficient } \\
\hline Newspaper Circulation & 0.121 & $(0.77)$ & - \\
\hline Constant & -0.91 & $(-0.12)$ & - \\
\hline \multirow{2}{*}{$\begin{array}{l}\text { Breusch-Pagan / Cook-Weisberg test for } \\
\text { heteroskedasticity }\end{array}$} & Chi2 & $=$ & 0.09 \\
\cline { 2 - 4 } & Prob>Chi2 & $=$ & 0.7694 \\
\hline
\end{tabular}

A similar finding is obtained when residuals of (log) deaths are regressed on newspaper circulation, as shown below in Table A.3.2. The OLS results do not show any relationship between the two variables.

Fig: A.3.1

Residual Natural Disasters and Newspaper Circulation

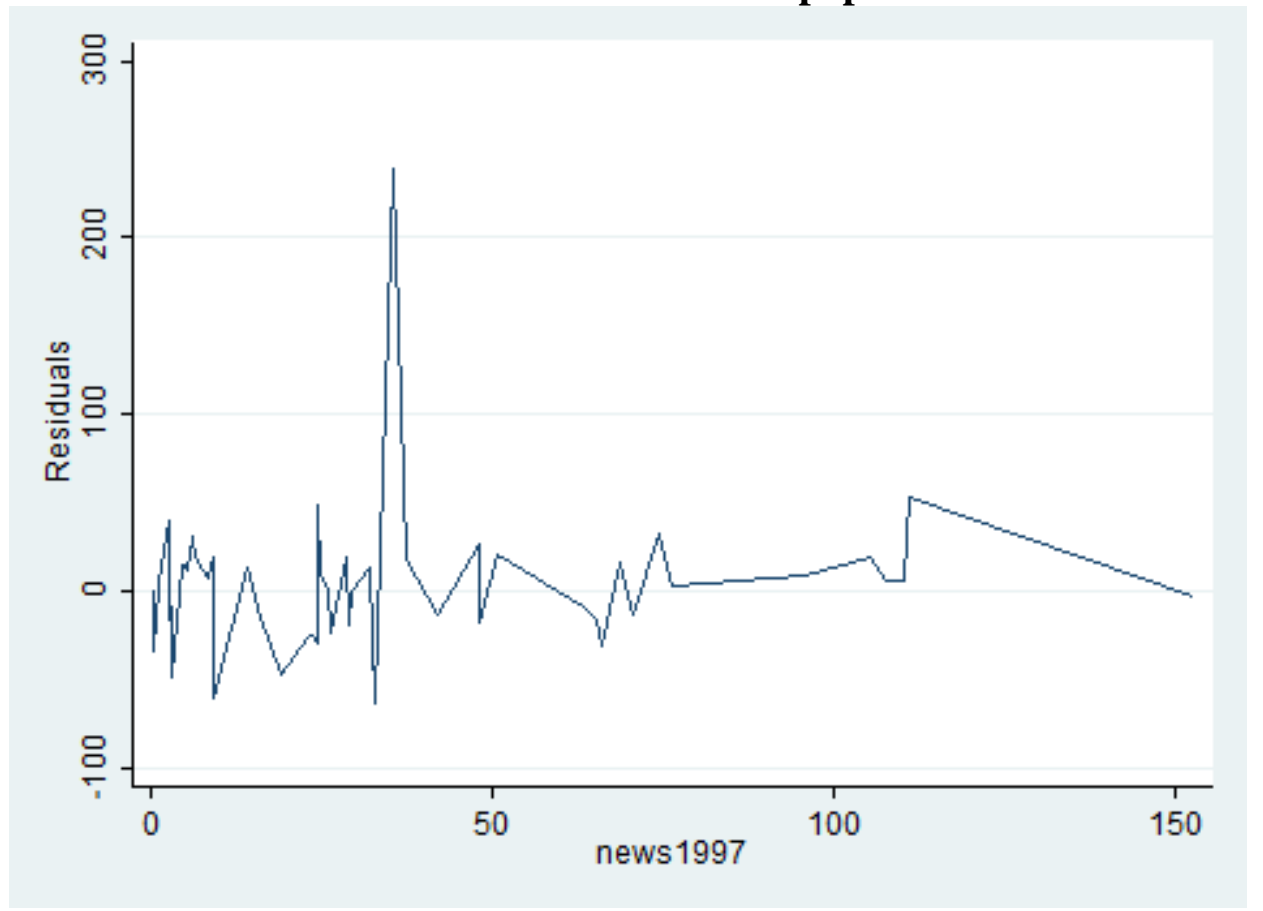


Table A.3.2

Residuals of (Log) Deaths and Exposure to Newspapers

\begin{tabular}{|l|rrl|}
\hline \multicolumn{4}{|c|}{ No. of observations $=55$} \\
\hline \multicolumn{4}{|c|}{$\mathrm{F}(1,53)=0.63$} \\
\hline \multicolumn{4}{|c|}{ Prob. $>\mathrm{F}=0.4298$} \\
\hline $\begin{array}{l}\text { Residual Log of deaths from disasters during 1980- } \\
\mathbf{2 0 0 4}\end{array}$ & -0.005 & $(0.80)$ & - \\
\hline Newspaper Circulation & 0.058 & $(0.19)$ & - \\
\hline Constant & Chi2 & $=$ & 0.27 \\
\hline $\begin{array}{l}\text { Breusch-Pagan / Cook-Weisberg test for } \\
\text { heteroskedasticity }\end{array}$ & Prob $>$ Chi2 & $=$ & 0.6032 \\
\hline
\end{tabular}

Fig: A.3.2

Residual Deaths from Natural Disasters and Newspaper Circulation

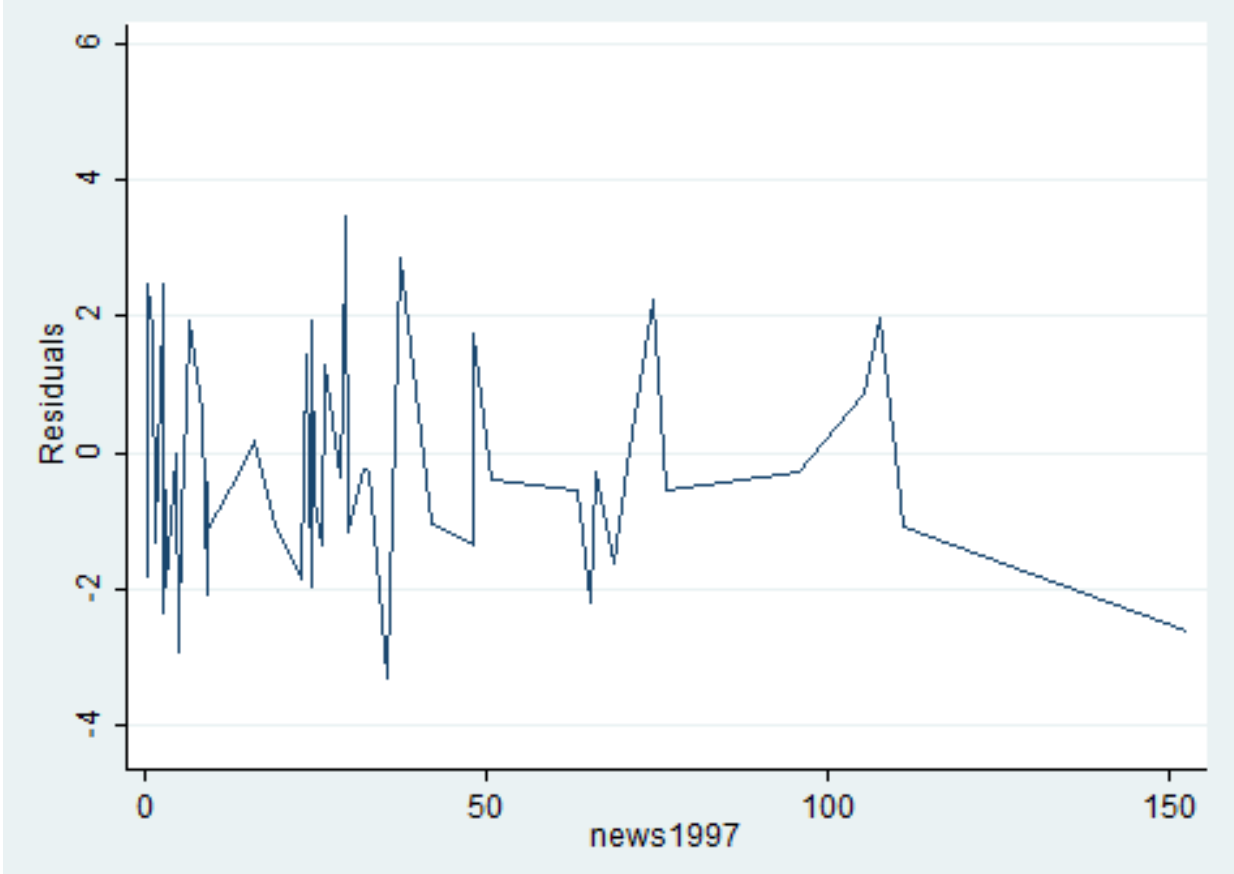

These results are further confirmed by the two graphs. The residuals do not vary systematically with newspaper circulation. 
Annex 4

Table A.4.1

List of Variables

\begin{tabular}{|c|c|}
\hline Variable & Description \\
\hline areakm $^{2}$ & land area $\left(\mathrm{km}^{2}\right)$ \\
\hline Small country & $<2000000 \mathrm{~km}^{2}$ \\
\hline Medium country & $2000000-750000 \mathrm{~km}^{2}$ \\
\hline Large country & $>750000 \mathrm{~km}^{2}$ \\
\hline elev & mean elevation (metres above sea level) \\
\hline distc & mean distance to nearest coastline $(\mathrm{km})$ \\
\hline pdenpavg & persons $/ \mathrm{km}^{2}$ \\
\hline landlock & whether a country is landlocked (outside of Western and Central Europe) \\
\hline ethnic & measure of ethnic fragmentation \\
\hline regd11 & Latin America and the Caribbean \\
\hline regd21 & South Asia \\
\hline regd22 & East Asia and the Pacific \\
\hline regd31 & Europe and Central Asia \\
\hline regd41 & Middle East and North Africa \\
\hline (default case) & Sub-Saharan Africa) \\
\hline incm_d1 & dummy takes the value 1 for Low Income countries \\
\hline incm_d2 & dummy takes the value 1 for Lower Middle Income countries \\
\hline (default case) & Upper Middle Income countries \\
\hline n_d-7-_79 & number of natural disasters during 1970-1979 \\
\hline n_d_90_04 & number of natural disasters during 1990-2004 \\
\hline n_d_80_89 & number of natural disasters during 1980-89 \\
\hline ld_d_80_04 & log of deaths from disasters during 1980-2004 \\
\hline ld_d_70_79 & log of deaths from disasters during 1970-79 \\
\hline
\end{tabular}




\section{References}

Andersen, T. J. (2005) "Applications of Risk Financing Techniques to Manage Economic Exposures to Natural Hazards”, Washington DC: Inter-American Development Bank, mimeo.

Alesina, A., A. Devleeschauwer, W. Easterly, S. Kurlat and R. Wacziarg (2003)“ Fractionalisation”, Journal of Economic Growth, vol. 8, no. 2.

Auffret, P. (2003) “High Consumption Volatility: The Impact of Natural Disasters?”, Washington DC: World Bank, mimeo.

Birkmann, J. (2006) (ed.) Measuring Vulnerability to Natural Hazards: Towards Disaster Resilient Societies, Tokyo: United Nations University Press, 2006.

Bloom, D. E., D. Canning and J. Sevilla (2003) “Geography and Poverty Traps”, Journal of Economic Growth, vol. 8, no. 4.

Brooks, N. and W. N. Adger (2005) "Country Level Risk Indicators from Outcome Data on ClimateRelated Disasters: An Exploration of the Emergency Events Database”, Norwich: East Anglia, mimeo.

Cole, S., A. Healy and E. Werker (2012) "Do Voters Demand Responsive Governments? Evidence from Indian Disaster Relief”, Journal of Development Economics, vol. 97, no. 2.

Dasgupta, P. (2007) Economics-A Very Short Introduction, Oxford: Oxford University Press.

Dreze, J. (1999) “Introduction” in J. Dreze (ed) The Economics of Famine, Cheltenham: Edward Elgar Publishing Ltd.

Dreze, J. and Amartya Sen (1989) Hunger and Public Action, Oxford: Clarendon Press.

Dyson, T. (1991) "On the Demography of South Asian Famines, Parts 1 and 2”, Population Studies, vol. 45, nos. 1 and 2, pp.5-25, \& 279-297.

Freeman, P. K., M. Keen and M. Mani (2003a) "Dealing with Increased Risk of Natural Disasters: Challenges and Options”, Washington DC: IMF Working Paper (WP/03/197).

Froot, K. A. (2001) “The Market for Catastrophic Risk: A Clinical Examination”, Journal of Financial Economics, vol. 60.

Froot, K. A. and P. G.J. O’Connell (1997) “On the Pricing of Intermediate Risks:Theory and Application to Catastrophe Reinsurance”, The Wharton School, University of Pennsylvania, mimeo.

Gaiha, R. and G. Thapa (2006) “Natural Disasters, Vulnerability and Mortalities”, Rome: Asia and the Pacific Division, IFAD, mimeo.

Gallup, J. L., J. D. Sachs and A. Mellinger (1999) “Geography and Economic Development”, International Regional Science Review, vol. 22.

Hallegatte, S. and V. Przyluski (2010) “The Economics of Natural Disasters: Concepts and Methods”, World Bank Policy Research Working Paper 5507, mimeo.

IFRC (International Federation of Red Cross and Red Crescent Societies (2001) World Disasters Report of 2001, Geneva.

IPCC (2007) “Climate Change 2007: Climate Change Impacts, Adaptation and Vulnerability-Summary for Policy Makers”, WGII Fourth Assessment Report, 6 April.

Kahn, M. E. (2005) "The Death Toll from Natural Disasters: The Role of Income, Geography, and Institutions”, Review of Economics and Statistics, vol. 87, no. 2, pp.271-284.

Kousky, C., E. Luttmer and R. Zeckhauser (2006) "Private Investment and Government Protection”, Journal of Risk and Uncertainty, vol. 33.

Kunreuther, H. (1997) “Managing Catastrophic Risks Through Insurance and Mitigation”, Paper presented at a conference on "Financial Risk Management for Natural Catastrophes", Gold Coast.

Lave, L.B., and J. Apt (2006) "Planning for Natural Disasters in a Stochastic World”, Journal of Risk and Uncertainty, vol. 33. 
Marris, E. (2005) “Inadequate Warning System Left Asia at the Mercy of Tsunami”, Nature, vol. 433, 6 January.

Mechler, R. (2003) Natural Disaster Risk Management and Financing Disaster Losses in Developing Countries, Ph.D thesis, Karlsruhe: Karlsruhe University.

Noy, I, (2009) “The Macroeconomic Consequences of Disasters”, Journal of Development Economics, vol. 88 ,

Oxfam (2005) The Tsunami's Impact on Women, http://www.oxfam.org.uk/what_we_do/issues/ conflict_disasters/downloads/bn_tsunami_women.pdf.

Renaud, F.G. (2006) “Environmental Components of Vulnerability”, in Birkmann (ed.).

Rohde, D. (2005) “Tsunami’s Cruellest Toll: Sons and Daughters Lost”, The New York Times, January 7.

Sachs, J. (2000) “Tropical Underdevelopment”, draft.

Sen, Amartya (1998) “Mortality as an Indicator of Economic Success and Failure”, The Economic Journal, vol. 108.

Sen, Amartya (1999) Development as Freedom, New York, Alfred A. Knopf

Starvish, M. (2011) “Doomsday Coping for Catastrophe Risk Insurers”, Harvard Business School, Research and Ideas, September.

Thomalla, F. and H. Schmuck (2004) "We all Knew That a Cyclone was Coming: Disaster Preparedness and Cyclone of 1999 in Orissa, India”, Disaster, vol. 28, no. 4.

Toya, H. and M. Skidmore (2007) "Economic Development and the Impacts of Natural Disasters", Economics Letters, vol. 94.

Viscusi, W. K. and R. J. Zeckhauser (2006) "National Survey Evidence on Disasters and Relief: RiskBeliefs, Self-Interest, and Compassion”, Journal of Risk and Uncertainty, vol. 33.

Viscusi, W. K. and R. J. Zeckhauser (2011) “Addressing Catastrophic Risks: Disparate Anatomies require Tailored Therapies”, RWP11-045, Harvard Kennedy School, mimeo.

Wisner, B. (2006) "Self-Assessment of Coping Capacity: Participatory, Proactive, and Qualitative Engagement of Communities in Their Own Risk Management" in Birkmann (ed.).

WDI (2006) World Development Indicators, Supplementary Notes and Definitions, Washington DC.

World Bank (2006b) Hazards of Nature, Risks to Development, Independent Evaluation Group, Washington DC.

World Bank (2010) Natural Hazards, Unnatural Disasters, Washington DC. 